Article

\title{
Bank Competition and Credit Risk in Euro Area Banking: Fragmentation and Convergence Dynamics
}

\author{
Maria Karadima ${ }^{1, *}$ and Helen Louri ${ }^{1,2}$ \\ 1 Department of Economics, Athens University of Economics and Business, 76 Patission Street, \\ GR-10434 Athens, Greece; elouri@aueb.gr \\ 2 European Institute/Hellenic Observatory, London School of Economics, Houghton Street, \\ London WC2A 2AE, UK \\ * Correspondence: karadimam@aueb.gr
}

Received: 9 February 2020; Accepted: 12 March 2020; Published: 16 March 2020

\begin{abstract}
Consolidation in euro area banking has been the major trend post-crisis. Has it been accompanied by more or less competition? Has it led to more or less credit risk? In all or some countries? In this study, we examine the evolution of competition (through market power and concentration) and credit risk (through non-performing loans) in 2005-2017 across all euro area countries (EA-19), as well as core (EA-Co) and periphery (EA-Pe) countries separately. Using Theil inequality and convergence analysis, our results support the continued existence of fragmentation as well as of divergence within and/or between core and periphery with respect to competition and credit risk, especially post-crisis, in spite of some partial reintegration trends. Policy measures supporting faster convergence of our variables would be helpful in establishing a real banking union.
\end{abstract}

Keywords: banking competition; credit risk; NPLs; Theil index; convergence analysis

JEL Classification: C23; G21

\section{Introduction}

Financial integration has been one of the major goals of the European Union (EU) because of its significant capability to offer more opportunities for risk sharing, better allocation of capital, and higher economic growth (Baele et al. 2004). Financial integration may be defined as "a situation whereby there are no frictions that discriminate between economic agents in their access to-and their investment of-capital, particularly on the basis of their location" (European Central Bank, ECB 2003). A related concept is financial fragmentation, which is often used to indicate some forms of imperfect integration (Claessens 2019). Fragmentation generally refers to financial markets, which fragment either by type of product/participant or geographically (Financial Stability Board, FSB 2019).

From the establishment of the European Monetary Union (EMU) up to the outbreak of the global financial crisis, the euro area witnessed a rapidly growing financial integration, which was evident in terms of both volume and prices (De Sola Perea and Van Nieuwenhuyze 2014). Financial integration was also expected to promote competition in the euro area banking sector (Casu and Girardone 2009), due inter-alia to increased disintermediation and cross-border competition (De Bandt and Davis 2000). Nevertheless, the financial crisis of 2008 reversed some advances in competitive pressure, which had been achieved until then (Maudos and Vives 2019).

Financial fragmentation peaked during the euro area debt crisis (2011-2012) and declined afterwards due to the measures taken by the ECB. According to Al-Eyd and Berkmen (2013), the unconventional monetary policy undertaken by the ECB was instrumental in reducing the overall degree of financial market fragmentation. Berenberg-Gossler and Enderlein (2016) confirm that after 
the ECB announcement of the Outright Monetary Transactions (OMT) program in 2012 there was a gradual, but often fragile, decline of financial fragmentation across all markets. After a temporary correction between late 2015 and 2016, the aggregate post-crisis reintegration trend in the euro area resumed with respect to prices. In contrast, the post-crisis reintegration trend with respect to quantities stalled in 2015, partly due to the supply of excess reserves from the ECB, which had reduced the need for counterparties to trade across borders (ECB 2018).

In this study, we test the hypothesis of the existence of fragmentation in the euro area (EA) as a whole (EA-19 group-19 countries of the Euro Area from 1 January, 2015), as well as in core countries (EA-Co group) and periphery countries (EA-Pe group), with respect to bank competition (through market power and concentration) and credit risk over the period 2005-2017. The group of core countries includes eleven countries (Austria, Belgium, Estonia, Germany, Finland, France, Latvia, Lithuania, Luxembourg, Netherlands, and Slovakia), while the periphery group includes eight countries (Cyprus, Greece, Ireland, Italy ${ }^{1}$, Malta, Portugal, Slovenia, and Spain). The periphery countries were hit by the 2008 financial crisis more severely than the core countries, while some of them (namely, Cyprus, Greece, Ireland, Slovenia, and Spain) received state aid through various impaired asset measures or direct state recapitalization. The classification of countries into each group is based on a prior identification from the European Commission of distinct groups of EU Member States, according to their levels of non-performing loans (NPLs) (Magnus et al. 2017). More specifically, the hypothesis of the existence of fragmentation is tested through the investigation of inequalities among the country-members of each group, as well as between EA-Co and EA-Pe, with respect to bank competition, bank concentration and credit risk. In total, four types of inequality—with respect to a given variable-are considered: (a) inequality between banks in a given country (within-country inequality), (b) inequality between banks of different countries belonging to the same group (between-country inequality), (c) inequality between banks or countries in a given group (within-group inequality), and (d) inequality between banks or countries of different groups (between-group inequality).

A second hypothesis, which is tested in this study, refers to the presence of $\beta$-convergence and $\sigma$-convergence ${ }^{2}$ among the country-members of each group, with respect to bank competition, bank concentration, and credit risk. It should be noted, however, that a possible convergence of the variables under examination is only a necessary but not a sufficient condition for the achievement of financial integration in the euro area.

The Lerner index for market power, used in our study as an inverse proxy for bank competition, has been calculated following the innovative stochastic frontier estimator of market power, suggested by Kumbhakar et al. (2012). Bank concentration, which also indicates the degree of competitive pressure, is measured by the Herfindahl-Hirschman Index (HHI) and the market share of the five largest banks (CR5). Credit risk is approximated by non-performing loans (NPLs). Finally, we use the Theil inequality index for the four variables to examine the evolution of inequality either within/between countries or within/between groups.

To the best of our knowledge, this is the first time in the empirical literature that the evolution and convergence of bank competition, concentration and credit risk are examined across EA-19, EA-Co and EA-Pe to test for continued fragmentation and converging or diverging trends. Our analysis, which employs a panel dataset of euro area banks from 2005 to 2017, extends beyond the period of financial crisis, thereby taking into account the non-standard measures adopted by the ECB to support further integration. By using data from all the 19 euro area countries, which have a common

1 While Italy should in principle be considered as a core country since it has been one of the EU founding members, it is classified in this study as a periphery country because of its high levels of NPLs during the crisis. A classification of Italy as a periphery country has also been made in other studies (see Al-Eyd and Berkmen 2013; Anastasiou et al. 2019; Louri and Migiakis 2019).

2 In the case of competition, for example, $\beta$-convergence would apply if countries with lower levels of competition were found to tend to catch up with countries characterized by higher levels of competition, while $\sigma$-convergence would apply if the dispersion of competition levels across countries showed a tendency to decline over time. 
currency and a single bank supervisory mechanism, a possible bias that might stem from the use of either heterogeneous data or data coming from only a subset of euro area countries was eliminated. In addition to uncovering the evolution of financial integration a major aim of our study was to provide substantiated clues to policy makers about the progress of integration and underline the need for further measures required to achieve a real banking union.

The use of an alternative measure of credit risk, such as the loan loss provisions (LLPs), was prohibited by the lack of non-available comparable data. In addition, the lack of bank-level data on total assets and NPLs did not facilitate the breakdown of total inequality in both bank concentration and credit risk into their within-country and between-country components, an issue that remains open for future research. Finally, since a limitation of this study is that countries with possibly different characteristics form a group on the basis of a priori classification, future research could use novel methods (e.g., Phillips and Sul 2007) to identify groups of countries that exhibit convergence ("convergence clubs").

The rest of the study is organized as follows. Section 2 describes the evolution of competitive conditions in EU banking. Sections 3-5 examine the evolution of bank competition, concentration and credit risk, respectively. Section 6 investigates the Theil inequality for bank competition, concentration and credit risk. Section 7 displays the convergence analysis, while Section 8 concludes.

\section{Evolution of Competitive Conditions in EU Banking}

\subsection{Before the Introduction of the Euro}

We classify the literature review on the evolution of competition in the European Union into three groups, according to the period examined by each study: (1) before the introduction of the euro in 1999, (2) around the introduction of the euro, and (3) after the introduction of the euro. The above classification has been made in order to facilitate the comparison of the results.

The first group of studies examines the degree of competition before the introduction of the euro in 1999. The major milestones of this period were: (1) the adoption of the Second Banking Directive (Directive 89/646/ European Economic Community (EEC) of 15 December, 1989), which entered into force on 1 January, 1993, providing a "passport" to European banks, which allowed a bank licensed in an EU country to establish branches or provide financial services in any of the other Member States, while the prudential supervision of a bank remained the responsibility of the home Member State; (2) the start of Stage One (1990-1993) of the EMU on 1 July, 1990, a date on which the restrictions on the free movement of goods, persons, capital and services between the EMU Member States were removed; (3) the establishment of the European Union with the signing of the Treaty on the European Union (the "Maastricht Treaty") on 7 February, 1992; and (4) the start of Stage Two (1994-1998) of the EMU on 1 January, 1994, with the establishment of the European Monetary Institute (EMI), whose task was to coordinate monetary policy among the central banks of the Member States and make all the necessary preparations for the introduction of the euro in Stage Three, starting from 1 January, 1999.

Bikker and Haaf (2002) examine the competitive conditions and concentration in 23 European and non-European industrialized countries over the period 1988-1998. Using the H-statistic, they find that all the banking markets under examination were characterized by monopolistic competition. Perfect competition could not be excluded for a number of European large-bank markets, while competition appeared to be higher in Europe than in Canada, Japan and the US. De Bandt and Davis (2000) investigate the effects of the EMU on the competitive conditions in France, Germany and Italy over the period 1992-1996. The H-statistic indicates that large banks in Germany and France operated in an environment of monopolistic competition, in contrast to small banks, which seemed to have some monopoly power. In Italy, both large and small banks operated under monopolistic competition. The H-statistic, calculated for the same period on a sample of US banks, indicates that the US banking system was more competitive than those of France, Germany and Italy. 
Some other studies of this group use cross-country data from the EU area only. Fernandez de Guevara et al. (2007) investigate the progress of financial integration in 15 EU countries. The study reveals the existence of convergence in interest rates during the period 1993-2001, which is attributed to the convergence of inflation rates and the decrease in nominal interest rates. By examining the evolution of the levels of competition, measured by the Lerner index, they find that market power increased about $10 \%$ on average in 10 of the 15 countries during the period 1993-2000. They also constructed a Theil inequality index for the Lerner index, which helped them to identify an increase in market power inequality in the 15 countries under examination. The decomposition of the Theil index into a within-country and a between-country component suggests that the main part of the market power inequality was within countries themselves (within-country inequality).

The rest of the studies in this group examine the case of one EU country only. Hondroyiannis et al. (1999) assess the competitive conditions in Greece over the period 1993-1995. The results, based on the use of the H-statistic, indicate that Greek banks operated in an environment characterized by monopolistic competition. These competitive conditions were formed as a result of the enactment of the EU Second Banking Directive, the lifting of controls on foreign exchange, and the liberalization of capital movements. Angelini and Cetorelli (2003) examine the banking competitive conditions in Italy over the period 1984-1997. Using the Lerner index for each of five geographical banking markets in Italy (i.e., Nationwide, North-East, North-West, Center, and South), they find that competitive conditions across the five areas remained relatively unchanged until 1992, before starting to improve thereafter as a result of the implementation of the EU Second Banking Directive in 1993. Another finding is that the large-scale bank consolidation in Italy during the 1990s not only did not worsen competitive conditions, but actually improved banks' efficiency. Coccorese (2004) examines the banking competitive conditions in Italy during the period 1997-1999. Using the H-statistic, he finds that banks operated under conditions of monopolistic competition at a national level. When banks are classified into four macro-regions (North-West, North-East, Center, and South and Islands), the results indicate that banks in both the North-West and the North-East regions operated in an environment characterized by perfect competition.

The conclusion that can be drawn from the first group of studies is that euro area banks operated under conditions of monopolistic competition during the pre-EMU period, while contradictory results have been derived regarding the sign of the change in competition levels.

\subsection{Around the Introduction of the Euro}

The second group of studies examines the competitive conditions in the EU during a period including a few years both before and after the introduction of the euro, which was introduced in 1999 but entered into circulation in 2002. For this reason, some studies (Apergis et al. 2016; Sun 2009) consider 2000 as the end year of the pre-EMU period and 2001 as the start year of the after-EMU period.

Some of the studies of this group employ data not only from the EU area but also from other geographical regions for comparison purposes. Bikker and Spierdijk (2008) examine the developments in bank competition in 101 countries worldwide during the period 1986-2004. Using the H-statistic, they find that the EU-15 (15 EU Member States from 1 January, 1995) experienced a major break in competitive conditions around 2001-2002, followed by a decrease of about $60 \%$ in competition. In contrast, nine Eastern European countries that have joined the EU since 2004 experienced a modest decrease of about 10\% in competition during the years 1994-2004. Sun (2009) assesses the degree of bank competition in the US, the UK and 10 euro area countries over the period 1995-2009. The results of the study indicate that the euro area experienced convergence of competition levels across member countries, as well as a decrease in competition, measured by the $\mathrm{H}$-statistic, after the introduction of the EMU (period 2001-2007). Competition also decreased during the crisis period (2008-2009), especially in countries where large credit and housing booms had been observed pre-crisis.

Some other studies of this group examine countries belonging to the EU area only, making in some cases a comparison between euro area and non-euro area countries. Staikouras and 
Koutsomanoli-Filippaki (2006) assess the competitive conditions in the EU-15 and EU-10 (10 EU Member States that joined in 2004) countries over the period 1998-2002. The results of the study, based on three different H-statistic specifications, indicate that banks in both the EU-15 and the EU-10 countries operated in an environment of monopolistic competition. Goddard et al. (2013) examine the convergence of bank profits in eight EU countries (Belgium, Denmark, France, Germany, Italy, Netherlands, Spain and the UK) over the period 1992-2007. They find that the average profitability was lower for banks that had a higher capital level, while banks that were more efficient and diversified were characterized by higher average profitability. Another finding is that excess profit presented weaker persistence during the years 1999-2007 than in the previous period 1992-1998, indicating that the introduction of the EU financial integration, especially with the adoption of the euro and the implementation of the Financial Services Action Plan (FSAP), intensified bank competition. Apergis et al. (2016) assess the level of bank competition across three EU economic blocks (EU-27-27 EU Member States from 1 January, 2007; EA-17-17 EA Member States from 1 January, 2011; and the remaining 12 EU countries) over the period 1996-2011. The H-statistic, calculated on the basis of three alternative specifications of both scaled and unscaled reduced-form revenue equations, indicates the presence of conditions of monopolistic competition across all the above economic blocks. Competition levels seemed to be lower in the EA-17 countries than in the EU-27 countries, which could be due to the increasing mergers and acquisitions in the EA-17 countries. The results also show that the competition level in the EA-17 countries decreased slightly in the post-EMU period (2001-2007), compared to the pre-EMU period (1996-2000), while the competition levels in the EA-17 countries showed a slight decline during the post-crisis period (2008-2011). The development of banking competition policy in the EU area, as well as the trends in bank competition and concentration, during the 25-year period 1992-2017, are examined by Maudos and Vives (2019). They find that the recent global financial crisis interrupted the process of normalization of the banking competition policy in the EU, which had started in the 1980s, and reversed the advances that had been made in competitive pressures due to the implementation of the Single Market initiative and the introduction of the euro. After the crisis, competition policy in the EU focused on limiting the distortions in competition created by the massive state aid granted to banks. They also find that the crisis accelerated the pace of bank concentration in the countries that had been hit most severely by the crisis and whose banking systems had been subject to restructuring.

Regarding studies that examine the case of only one country, Gischer and Stiele (2008) examine the banking competitive conditions in Germany over the period 1993-2002. Using the H-statistic on a dataset of more than 400 cooperative banks (Sparkassen), they find that these banks operated under conditions of monopolistic competition. In addition, the H-statistic for small cooperative banks was lower than for large cooperative banks, suggesting that smaller cooperative banks seemed to enjoy more market power than larger ones.

In summary, the second group of studies suggests that banks in the euro area operated under conditions of monopolistic competition during the period around the introduction of the euro. The results regarding the impact of the introduction of the euro on bank competition are contradictory, with most studies suggesting a decline in competition during the post-EMU period.

\subsection{After the Introduction of the Euro}

The third group of studies examines the evolution of competition well after the introduction of the euro. Some of these studies examine the case of more than one EU country. Casu and Girardone (2009) assess the effects of the EU deregulation and competition policies on bank concentration and competition in the five largest EU banking markets (France, Germany, Italy, Spain, and the UK) over the period 2000-2005. Using the HHI and CR5 concentration indices, they observe an increasing degree of bank concentration during the period under examination, with the exception of Spain. Furthermore, the values of concentration indices vary significantly across countries. Their findings are confirmed when a sub-sample of only commercial banks is taken into account. The use of the Lerner index did not provide 
any evidence that competition increased until 2005, while the results derived from the estimation of H-statistics indicate conditions of monopolistic competition in all five countries. Weill (2013) investigates whether economic integration in the European Union banking industries has favored bank competition over the period 2002-2010, by following two different approaches. First, he examines the evolution of competition in the EU-27 countries, as measured by the Lerner index and the H-statistic. The results do not confirm a general improvement of bank competition over the entire period under examination. In contrast, a small increase of the Lerner index was observed during the pre-crisis period, which, however, slowed down after the outbreak of the global financial crisis, in particular in the case of the twelve new EU member countries. Second, he employs $\beta$-convergence and $\sigma$-convergence tests on the Lerner index and the H-statistic, which suggest that during the period 2002-2010 the least competitive banking systems had experienced a greater improvement in competition than the most competitive banking systems, while the disparity in competition levels among the EU-27 countries was reduced. The impact of the 2008 global crisis on the fragmentation of the banking system in 11 euro area countries over the period 1999-2011 was examined by Lucotte (2015) who uses ten different harmonized banking indicators covering the areas of concentration and competition, efficiency, stability, development, and activity. Using a hierarchical cluster analysis, he indicates the existence of large dissimilarities since the creation of the euro area between Greece and Italy on the one hand, and the other nine countries on the other. The nine countries were split after 2008 into two different clusters with large dissimilarities. The first cluster comprises Austria, Belgium, Finland, France, and Germany, while Ireland, Netherlands, Portugal, and Spain belong to the other. Cruz-Garcia et al. (2017) investigate the impact of financial market integration on the evolution of disparities among European banks' market power. They use bank-specific data for the EA-12 countries (12 EA Member States from 1 January, 2001) over the period 2000-2014, and find that the Lerner index of bank market power increased in 10 of the 12 countries. Using a Theil inequality index for the Lerner index, they find that while the differences in market power between European banks decreased significantly over the period 2000-2014, significant and persistent differences in market power existed between banks in the same country.

Regarding studies of this group that examine the case of only one country, Moch (2013) investigates the competition conditions in Germany over the period 2001-2009. Using the H-statistic on a dataset comprising data from 1888 private, savings and cooperative banks, the study finds that interpretations about competitive conditions that are based on $\mathrm{H}$-statistic calculated at a national level can be distorted when the banking market is fragmented, as in Germany. When examining separately the three banking pillars in Germany (i.e., private, savings, and cooperative banks), the hypothesis for the presence of monopoly power in any of these pillars was definitely rejected. Savings and cooperative banks seemed to operate either under monopolistic conditions in a long-run equilibrium or under long-run competitive conditions with flat average cost functions, while the private banks operated in a long-run competitive equilibrium.

In summary, the third group of studies suggests that monopolistic competition has been the dominant form of bank competition in the euro area after the introduction of the euro. The results regarding the evolution of competition are either inconclusive or suggest a decrease in competition levels after the 2008 global financial crisis.

A conclusion that can be drawn from all the studies presented in this section is that there is general agreement in the literature that banks in the euro area operated under conditions of monopolistic competition during the last 25 years. On the other hand, contradictory results are obtained regarding the impact of the introduction of the euro on the level of bank competition. This lack of consensus may be due to differences in the competition measures used, as well as to differences in the data employed with respect to geographical and time coverage. 


\section{Bank Competition in the Euro Area}

\subsection{Measuring Bank Competition through Market Power}

The literature on the measurement of competition follows two major approaches: the structural and the non-structural. The structural approach, which has its roots in the traditional Industrial Organization theory, embraces the Structure-Conduct-Performance (SCP) paradigm and the Efficiency Structure Hypothesis (ESH). The SCP paradigm states that a higher degree of concentration is likely to cause collusive behavior among the larger banks, resulting in superior market performance. Because of their ability to capture structural features of a market, concentration ratios are often used to proxy for competition. The most frequently used concentration ratios are the Herfindahl-Hirschman Index (HHI) and the k-bank concentration ratios (CRk). The HHI index is the sum of the squares of the market shares in total banking assets of all banks in a banking system, while the CRk concentration ratio is the sum of the shares of the $k$ largest banks. The Efficiency Structure Hypothesis (ESH) investigates the relationship between the efficiency of larger banks and their performance. A widely used ESH indicator is the Boone indicator (Boone 2008), which is calculated as the elasticity of profits or market share to marginal costs. The idea underlying the Boone indicator is that competition improves the performance or market share of efficient firms and weakens the performance or market share of inefficient ones.

The non-structural approach developed on the basis of the New Empirical Industrial Organization (NEIO) theory assesses the competitive behavior of firms without having to rely on information about the structure of the market. The H-statistic, developed by Panzar and Rosse (1987), and the Lerner index, developed by Lerner (1934), are the most well-known non-structural measures of competition. The Panzar and Rosse's model employs firm-level data to investigate the degree to which a change in input prices is reflected in equilibrium revenues. This model uses the $\mathrm{H}$-statistic, which takes a negative value to indicate a monopoly, a value between 0 and 1 to indicate monopolistic competition and the value 1 to indicate perfect competition. The Lerner index is a direct measure of a bank's market power. It represents the markup of prices over marginal cost and its value theoretically ranges between 0 (perfect competition) and 1 (pure monopoly). In practice, however, negative values may be observed for banks that face problems.

In our study, bank market power is measured by the Lerner index $(L)$, which identifies the degree of monopoly power as the difference between the price $(P)$ of a firm and its marginal cost $(M C)$ at the profit-maximizing rate of output:

$$
L=\frac{P-M C}{P}
$$

A zero value of the Lerner index indicates competitive behavior, while a bigger distance between price and marginal cost is associated with greater market power.

In contrast to $P$, the value of $M C$ is not directly observable, so we derive its value from the estimation of the following translog cost function:

$$
\begin{aligned}
& \operatorname{lnTC} C_{i t}=\alpha_{0}+\alpha_{Q} \ln Q_{i t}+0.5 \alpha_{Q Q}\left(\ln Q_{i t}\right)^{2}+\sum_{k=1}^{3} \alpha_{k} \ln W_{k, i t}+\sum_{k=1}^{3} \alpha_{Q k} \ln Q_{i t} \ln W_{k, i t} \\
& +0.5 \sum_{j=1}^{3} \sum_{k=1}^{3} \alpha_{j k} \ln W_{j, i t} \ln W_{k, i t}+\alpha_{E} \ln E_{i t}+0.5 \alpha_{E E}\left(\ln E_{i t}\right)^{2}+\sum_{k=1}^{3} \alpha_{E k} \ln E_{i t} \ln W_{k, i t} \\
& +\alpha_{E Q} \ln E_{i t} \ln Q_{i t}+\alpha_{T} T+0.5 \alpha_{T T} T^{2}+\alpha_{T Q} T \ln Q_{i t}+\sum_{k=1}^{3} \alpha_{T k} T \ln W_{k, i t}+\varepsilon_{i t}
\end{aligned}
$$

where TC is total cost (sum of total interest and non-interest expenses), $Q$ is total assets (proxy for bank output), $W_{1}$ is the ratio of other operating expenses to total assets (proxy for input price of capital), $W_{2}$ is the ratio of personnel expenses to total assets (proxy for input price of labor), $W_{3}$ is the ratio of total interest expenses to total funding (proxy for input price of funds), $T$ is a time trend variable, $E$ is total equity and $\varepsilon_{i t}$ is the error term. The subscripts $i$ and $t$ denote bank $i$ and year $t$, respectively. 
The time trend $(T)$ has been included in (2) to account for advances in banking technology. We have also included in (2) the level of Total Equity $(E)$, since it can be used in loan funding as a substitute for deposits or other borrowed funds.

Symmetry conditions have been applied to the translog portion of (2), while the restriction of linear homogeneity in input prices is imposed by dividing in (2) both total cost and input prices by one of the input prices.

$$
\begin{gathered}
\ln \left(\frac{T C_{i t}}{W_{3, i t}}\right)=\alpha_{0}+\alpha_{Q} \ln Q_{i t}+0.5 \alpha_{Q Q}\left(\ln Q_{i t}\right)^{2}+\sum_{k=1}^{2} \alpha_{k} \ln \left(\frac{W_{k, i t}}{W_{3, i t}}\right) \\
+\sum_{k=1}^{2} \alpha_{Q k} \ln Q_{i t} \ln \left(\frac{W_{k, i t}}{W_{3, i t}}\right)+0.5 \sum_{j=1}^{2} \sum_{k=1}^{2} \alpha_{j k} \ln \left(\frac{W_{j, i t}}{W_{3, i t}}\right) \ln \left(\frac{W_{k, i t}}{W_{3, i t}}\right) \\
+\alpha_{E} \ln E_{i t}+0.5 \alpha_{E E}\left(\ln E_{i t}\right)^{2}+\sum_{k=1}^{2} \alpha_{E k} \ln E_{i t} \ln \left(\frac{W_{k, i t}}{W_{3, i t}}\right)+\alpha_{E Q} \ln E_{i t} \ln Q_{i t} \\
+\alpha_{T} T+0.5 \alpha_{T T} T^{2}+\alpha_{T Q} T \ln Q_{i t}+\sum_{k=1}^{2} \alpha_{T k} T \ln \left(\frac{W_{k, i t}}{W_{3, i t}}\right)+\varepsilon_{i t}
\end{gathered}
$$

\subsection{Calculation of a Lerner Index Using a Stochastic Frontier Methodology}

The traditional approach of first estimating Equation (3) and then using the derived coefficient values to calculate marginal cost $(M C)$ is based on the unrealistic assumption that all firms are profit maximizers. This approach may also produce negative values for the Lerner index, although this should normally be expected to be non-negative. These problems can be solved by employing the innovative procedure suggested by Kumbhakar et al. (2012) who draw on a stochastic frontier methodology from the efficiency literature to estimate the mark-up for each observation.

Starting from the fact that a profit-maximizing behavior of a bank $i$ at time $t$ requires that

$$
P_{i t} \geq M C_{i t} \equiv \frac{\partial T C_{i t}}{\partial Q_{i t}}
$$

where $P$ is defined as the ratio of total revenues (total interest and non-interest income) to total assets, and after doing some mathematics, we arrive at the following equation:

$$
\frac{T R_{i t}}{T C_{i t}}=\frac{\partial \ln T C_{i t}}{\partial \ln Q_{i t}}+v_{i t}+u_{i t}
$$

where TR denotes the total revenues, $v_{i t}$ is a symmetric two-sided noise term, which is included in (5) to capture the possibility that the total revenue share in total cost might by affected by other unobserved variables, and $u_{i t}$ is a non-negative term, which captures the mark-up. This way, Equation (5) becomes a stochastic frontier function, where

$$
\frac{\partial \ln T C_{i t}}{\partial \ln Q_{i t}}+v_{i t}
$$

represents the stochastic frontier of TRit/TCit, i.e., the minimum level that TRit/TCit can reach.

Taking the partial derivative in (3), we get:

$$
\frac{\partial \ln T C_{i t}}{\partial \ln Q_{i t}}=\alpha_{Q}+\alpha_{Q Q} \ln Q_{i t}+\sum_{k=1}^{2} \alpha_{Q k} \ln \left(\frac{W_{k, i t}}{W_{3, i t}}\right)+\alpha_{E Q} \ln E_{i t}+\alpha_{T Q} T
$$

Substituting (6) into (5), we get:

$$
\frac{T R_{i t}}{T C_{i t}}=\alpha_{Q}+\alpha_{Q Q} \ln Q_{i t}+\sum_{k=1}^{2} \alpha_{Q k} \ln \left(\frac{W_{k, i t}}{W_{3, i t}}\right)+\alpha_{E Q} \ln E_{i t}+\alpha_{T Q} T+v_{i t}+u_{i t}
$$


Using the maximum likelihood method, Equation (7) is estimated separately for each country in order to account for different banking technologies per country. The estimation procedure is based on the distributional assumption that the non-negative term $u_{i t}$ is independently half-normally distributed with mean 0 and variance $\sigma_{\mathrm{u}}{ }^{2}$, while $v_{i}$ is independently normally distributed with mean 0 and variance $\sigma_{\mathrm{v}}{ }^{2}$. The estimation of (7) also allows to calculate the Jondrow et al. (1982) conditional mean estimator of $u_{\mathrm{it}}$.

The estimated parameters from (7) are substituted into (6) to calculate $\left(\partial \ln T C_{i t}\right) /\left(\partial \ln Q_{i t}\right)$ and, after omitting $v_{i t}$ from (5) and doing some calculations, we finally get:

$$
\frac{P_{i t}-M C_{i t}}{M C_{i t}}=u_{i t} \frac{1}{\frac{\partial \ln T C_{i t}}{\partial \ln Q_{i t}}}
$$

The left part of (8) contains a definition of mark-up, labelled by Kumbhakar et al. (2012) as $\Theta_{i t}$, where the distance between price and marginal cost is a fraction of the marginal cost. Then, the Lerner index is calculated from $\Theta_{i t}$ as follows:

$$
L_{i t}=\frac{\Theta_{i t}}{1+\Theta_{i t}}
$$

\subsection{Evolution of the Lerner Index of Bank Market Power}

The evolution of the Lerner index, which is calculated using an unbalanced panel dataset containing 13,890 observations from the unconsolidated balance sheets of 1442 commercial, savings, and mortgage banks from all euro area countries, is presented in Table 1 and in Figure 1. The data have been collected from the Orbis BankFocus (BankScope) Database provided by Bureau van Dijk.

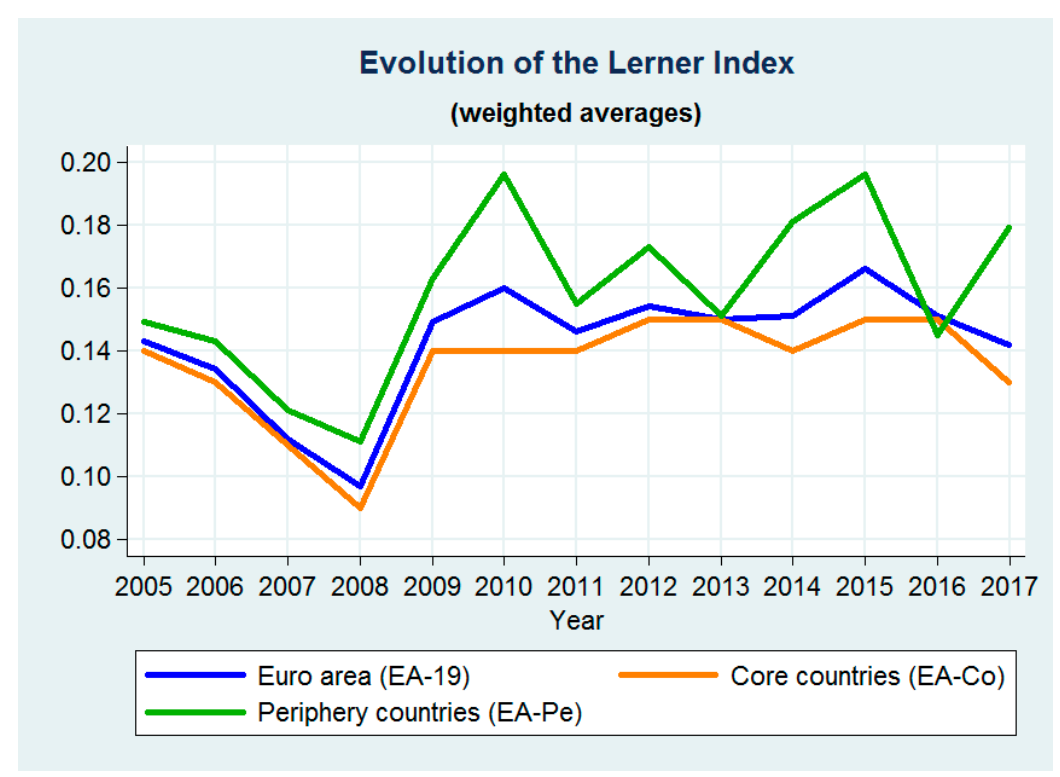

Figure 1. Evolution of the Lerner index of market power. Source: BankScope database, own calculations.

The country-level reported values have been obtained by taking the weighted average of the Lerner index values of individual banks, using as weights the country-level shares of individual banks in terms of total assets ${ }^{3}$. The total assets of banks per country and year have been obtained from the ECB Statistical Data Warehouse (ECB 2019a).

3 In this study, we preferred the weighted euro area averages to unweighted ones, because it is only the weighted averages that can take into account the large differences between euro area countries with regard to total banking assets. 
Table 1. Evolution of the Lerner index of market power.

\begin{tabular}{|c|c|c|c|c|c|c|c|c|c|c|c|c|c|c|c|}
\hline Country & 2005 & 2006 & 2007 & 2008 & 2009 & 2010 & 2011 & 2012 & 2013 & 2014 & 2015 & 2016 & 2017 & $\begin{array}{l}\text { Total } \\
\text { Change }\end{array}$ & $\begin{array}{l}\text { Coeff. } \\
\text { Var (\%) }\end{array}$ \\
\hline \multicolumn{16}{|c|}{ Euro Area Core Countries (EA-Co) } \\
\hline Austria & 0.142 & 0.112 & 0.096 & 0.096 & 0.117 & 0.128 & 0.125 & 0.116 & 0.139 & 0.133 & 0.150 & 0.136 & 0.189 & 0.047 & 18.9 \\
\hline Belgium & 0.194 & 0.213 & 0.129 & 0.099 & 0.113 & 0.159 & 0.153 & 0.112 & 0.135 & 0.123 & 0.170 & 0.146 & 0.147 & -0.047 & 22.6 \\
\hline Estonia & 0.107 & 0.133 & 0.201 & 0.110 & 0.046 & 0.090 & 0.114 & 0.137 & 0.223 & 0.167 & 0.205 & 0.240 & 0.242 & 0.135 & 40.4 \\
\hline Finland & 0.129 & 0.165 & 0.135 & 0.124 & 0.225 & 0.255 & 0.220 & 0.257 & 0.199 & 0.209 & 0.285 & 0.321 & 0.174 & 0.045 & 29.7 \\
\hline France & 0.185 & 0.177 & 0.119 & 0.100 & 0.190 & 0.154 & 0.138 & 0.168 & 0.162 & 0.137 & 0.178 & 0.200 & 0.141 & -0.044 & 18.7 \\
\hline Germany & 0.111 & 0.085 & 0.085 & 0.071 & 0.100 & 0.113 & 0.131 & 0.128 & 0.121 & 0.118 & 0.115 & 0.108 & 0.108 & -0.003 & 16.5 \\
\hline Latvia & 0.211 & 0.182 & 0.166 & 0.158 & 0.183 & 0.163 & 0.165 & 0.196 & 0.218 & 0.215 & 0.232 & 0.243 & 0.185 & -0.026 & 14.4 \\
\hline Lithuania & 0.164 & 0.162 & 0.128 & 0.097 & 0.121 & 0.118 & 0.071 & 0.108 & 0.137 & 0.178 & 0.112 & 0.193 & 0.186 & 0.022 & 27.3 \\
\hline Luxembourg & 0.160 & 0.175 & 0.143 & 0.145 & 0.245 & 0.250 & 0.215 & 0.260 & 0.296 & 0.298 & 0.329 & 0.287 & 0.253 & 0.093 & 26.5 \\
\hline Netherlands & 0.084 & 0.088 & 0.121 & 0.100 & 0.101 & 0.166 & 0.153 & 0.091 & 0.153 & 0.155 & 0.108 & 0.071 & 0.068 & -0.016 & 30.3 \\
\hline Slovakia & 0.116 & 0.126 & 0.109 & 0.105 & 0.137 & 0.157 & 0.168 & 0.118 & 0.126 & 0.128 & 0.146 & 0.174 & 0.080 & -0.036 & 20.3 \\
\hline Coeff. Var (\%) & 27.8 & 28.0 & 24.7 & 22.3 & 41.9 & 32.7 & 28.5 & 38.7 & 31.4 & 32.0 & 39.3 & 39.5 & 37.1 & & \\
\hline EA-Co average & 0.140 & 0.130 & 0.107 & 0.091 & 0.142 & 0.144 & 0.142 & 0.145 & 0.149 & 0.139 & 0.154 & 0.153 & 0.128 & -0.012 & 13.4 \\
\hline \multicolumn{16}{|c|}{ Euro Area Periphery Countries (EA-Pe) } \\
\hline Cyprus & 0.102 & 0.236 & 0.233 & 0.103 & 0.146 & 0.167 & 0.103 & 0.154 & 0.184 & 0.295 & 0.331 & 0.318 & 0.216 & 0.114 & 40.4 \\
\hline Greece & 0.159 & 0.127 & 0.086 & 0.085 & 0.091 & 0.075 & 0.101 & 0.119 & 0.056 & 0.067 & 0.080 & 0.111 & 0.128 & -0.031 & 29.2 \\
\hline Ireland & 0.036 & 0.016 & 0.016 & 0.068 & 0.153 & 0.224 & 0.209 & 0.140 & 0.217 & 0.224 & 0.285 & 0.141 & 0.194 & 0.158 & 60.1 \\
\hline Italy & 0.142 & 0.138 & 0.109 & 0.098 & 0.110 & 0.117 & 0.109 & 0.129 & 0.126 & 0.145 & 0.142 & 0.103 & 0.138 & -0.004 & 13.5 \\
\hline Malta & 0.178 & 0.192 & 0.215 & 0.209 & 0.217 & 0.196 & 0.161 & 0.237 & 0.219 & 0.224 & 0.212 & 0.251 & 0.166 & -0.012 & 12.9 \\
\hline Portugal & 0.163 & 0.193 & 0.147 & 0.128 & 0.154 & 0.179 & 0.118 & 0.109 & 0.088 & 0.130 & 0.192 & 0.159 & 0.233 & 0.070 & 25.9 \\
\hline Slovenia & 0.120 & 0.128 & 0.142 & 0.074 & 0.121 & 0.158 & 0.145 & 0.172 & 0.156 & 0.154 & 0.122 & 0.145 & 0.106 & -0.014 & 19.4 \\
\hline Spain & 0.207 & 0.202 & 0.181 & 0.143 & 0.237 & 0.295 & 0.207 & 0.251 & 0.187 & 0.240 & 0.264 & 0.202 & 0.231 & 0.024 & 18.1 \\
\hline Coeff. Var (\%) & 38.1 & 44.4 & 50.3 & 40.8 & 32.9 & 37.7 & 30.9 & 32.5 & 38.7 & 39.7 & 42.5 & 41.5 & 27.9 & & \\
\hline EA-Pe average & 0.150 & 0.144 & 0.122 & 0.111 & 0.163 & 0.196 & 0.155 & 0.174 & 0.151 & 0.181 & 0.196 & 0.145 & 0.179 & 0.030 & 16.4 \\
\hline \multicolumn{16}{|c|}{ All Euro Area Countries (EA-19) } \\
\hline Coeff. Var (\%) & 31.4 & 35.1 & 37.6 & 30.7 & 37.2 & 34.5 & 28.7 & 35.2 & 33.8 & 35.0 & 40.0 & 39.3 & 32.6 & & \\
\hline EA-19 average & 0.143 & 0.134 & 0.112 & 0.097 & 0.149 & 0.160 & 0.146 & 0.154 & 0.150 & 0.151 & 0.166 & 0.151 & 0.142 & -0.001 & 13.3 \\
\hline
\end{tabular}

Notes: Total change is the difference between the value for 2017 and the value for 2005. Coeff. Var (\%) stands for the percent Coefficient of Variation measure. All average values are weighted by total banking assets. Source: BankScope database, own calculations. 
As shown in Table 1 and in Figure 1, the weighted average of market power in EA-19 initially followed a decreasing path arriving at a minimum value in 2008. Afterwards it started increasing, reaching a peak in 2015. It started falling in 2016, reaching in 2017 a value that is close to its corresponding value for 2005. On the other hand, the row-wise and column-wise coefficients of variation $^{4}$ in Table 1 show that there are significant disparities in market power not only between countries for each year but also between different years for the same country. In Ireland, market power increased between 2005 and 2017 by about 16 percentage points, while the biggest decrease of about 5 percentage points was observed in Belgium.

Regarding the other two country groups under examination, the weighted average of market power in EA-Pe has been persistently higher, also presenting more fluctuation, than market power in EA-Co during almost all years of the period under study. From 2009 onwards, as it is shown in Table 1 and in Figure 2, the disparities between EA-Co countries, measured by the coefficient of variation, have been moving almost in parallel with those between EA-Pe countries, both fluctuating between $30 \%$ and $40 \%$.

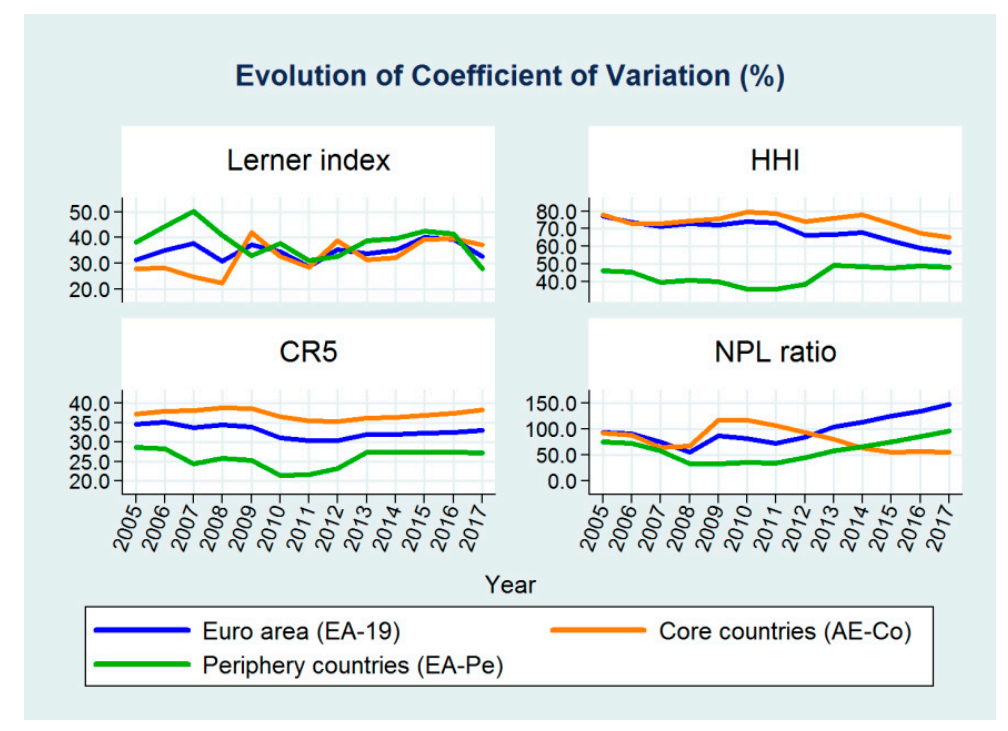

Figure 2. Evolution of the Coefficient of Variation (\%). Source: BankScope database, European Central Bank (ECB), World Bank, own calculations.

Unfortunately, the evolution of market power disparities in each group (EA-Co and EA-Pe) separately does not provide adequate information on which part of the disparities is due to differences inside each group (within-group inequality), and which part comes from differences between these two groups (between-group inequality). This task was accomplished by employing the Theil index and the relevant results are presented in Section 6.2.

\section{Bank Concentration in the Euro Area}

\subsection{The Evolution of the Herfindahl-Hirschman Index (HHI)}

The Herfindahl-Hirschman Index (HHI) is defined as the sum of the squares of the market shares in total banking assets of all banks in a banking system. An HHI value below 1000 indicates low concentration, a value between 1000 and 1800 indicates moderate concentration, and a value above 1800 indicates high concentration. The HHI evolution for the three country groups under examination is presented in Table 2 and in Figure 3. Country-level data from the ECB Statistical Data Warehouse (ECB 2019b) are used.

4 The coefficient of variation is defined as the ratio of the standard deviation to the mean. It shows the degree of variability in relation to the mean. 
Table 2. Evolution of concentration (Herfindahl-Hirschman Index, HHI).

\begin{tabular}{|c|c|c|c|c|c|c|c|c|c|c|c|c|c|c|c|}
\hline Country & 2005 & 2006 & 2007 & 2008 & 2009 & 2010 & 2011 & 2012 & 2013 & 2014 & 2015 & 2016 & 2017 & $\begin{array}{c}\text { Total } \\
\text { Change }\end{array}$ & $\begin{array}{l}\text { Coeff. } \\
\text { Var (\%) }\end{array}$ \\
\hline \multicolumn{16}{|c|}{ Euro Area Core Countries (EA-Co) } \\
\hline Austria & 560 & 534 & 527 & 454 & 414 & 383 & 423 & 395 & 405 & 412 & 397 & 358 & 374 & -186 & 18.9 \\
\hline Belgium & 2112 & 2041 & 2079 & 1881 & 1622 & 1439 & 1294 & 1061 & 979 & 981 & 998 & 1017 & 1102 & -1010 & 22.6 \\
\hline Estonia & 4039 & 3593 & 3410 & 3120 & 3090 & 2929 & 2613 & 2493 & 2483 & 2445 & 2409 & 2406 & 2419 & -1620 & 40.4 \\
\hline Finland & 3130 & 3010 & 2970 & 3490 & 3480 & 3830 & 3880 & 3250 & 3410 & 3630 & 3160 & 2300 & 1700 & -1430 & 29.7 \\
\hline France & 727 & 726 & 679 & 681 & 605 & 610 & 600 & 545 & 568 & 584 & 589 & 572 & 574 & -153 & 18.7 \\
\hline Germany & 174 & 178 & 183 & 191 & 206 & 301 & 317 & 307 & 266 & 300 & 273 & 277 & 250 & 76 & 16.5 \\
\hline Latvia & 1176 & 1270 & 1158 & 1205 & 1181 & 1005 & 929 & 1027 & 1037 & 1001 & 1033 & 1080 & 1235 & 59 & 14.4 \\
\hline Lithuania & 1838 & 1913 & 1827 & 1714 & 1693 & 1545 & 1871 & 1749 & 1892 & 1818 & 1939 & 1938 & 2189 & 351 & 27.3 \\
\hline Luxembourg & 373 & 333 & 316 & 309 & 310 & 343 & 346 & 345 & 357 & 330 & 321 & 260 & 256 & -117 & 26.5 \\
\hline Netherlands & 1796 & 1822 & 1928 & 2167 & 2034 & 2049 & 2067 & 2026 & 2105 & 2131 & 2104 & 2097 & 2087 & 291 & 30.3 \\
\hline Slovakia & 1076 & 1131 & 1082 & 1197 & 1273 & 1239 & 1268 & 1221 & 1215 & 1221 & 1250 & 1264 & 1332 & 256 & 20.3 \\
\hline Coeff. Var $(\%)$ & 77.8 & 73.0 & 72.9 & 74.3 & 75.7 & 79.5 & 78.5 & 73.9 & 75.9 & 78.1 & 73.1 & 67.3 & 65.0 & & \\
\hline EA-Co average & 711 & 714 & 733 & 757 & 713 & 742 & 767 & 713 & 705 & 746 & 724 & 695 & 663 & -48 & 3.8 \\
\hline \multicolumn{16}{|c|}{ Euro Area Periphery Countries (EA-Pe) } \\
\hline Cyprus & 1029 & 1056 & 1089 & 1017 & 1085 & 1125 & 1030 & 1007 & 1645 & 1445 & 1443 & 1366 & 1962 & 933 & 40.4 \\
\hline Greece & 1096 & 1101 & 1096 & 1172 & 1183 & 1214 & 1278 & 1487 & 2136 & 2195 & 2254 & 2332 & 2307 & 1211 & 29.2 \\
\hline Ireland & 600 & 600 & 700 & 661 & 714 & 700 & 645 & 630 & 671 & 673 & 672 & 636 & 658 & 58 & 60.1 \\
\hline Italy & 230 & 220 & 328 & 307 & 298 & 410 & 407 & 410 & 406 & 424 & 435 & 452 & 519 & 289 & 13.5 \\
\hline Malta & 1330 & 1171 & 1177 & 1236 & 1250 & 1181 & 1203 & 1313 & 1458 & 1648 & 1620 & 1602 & 1599 & 269 & 12.9 \\
\hline Portugal & 1154 & 1134 & 1098 & 1114 & 1150 & 1207 & 1206 & 1191 & 1197 & 1164 & 1215 & 1181 & 1220 & 66 & 25.9 \\
\hline Slovenia & 1369 & 1300 & 1282 & 1268 & 1256 & 1160 & 1142 & 1115 & 1045 & 1026 & 1077 & 1147 & 1133 & -236 & 19.4 \\
\hline Spain & 487 & 442 & 459 & 497 & 507 & 528 & 596 & 654 & 719 & 839 & 896 & 937 & 965 & 478 & 18.1 \\
\hline Coeff. Var (\%) & 46.0 & 45.4 & 39.6 & 40.6 & 40.0 & 35.8 & 35.9 & 38.4 & 49.4 & 48.6 & 47.9 & 48.7 & 48.0 & & \\
\hline EA-Pe average & 480 & 462 & 520 & 526 & 540 & 594 & 604 & 626 & 681 & 726 & 754 & 765 & 812 & 332 & 18.6 \\
\hline \multicolumn{16}{|c|}{ All Euro Area Countries (EA-19) } \\
\hline Coeff. Var (\%) & 77.2 & 73.5 & 71.3 & 72.8 & 72.2 & 74.1 & 73.2 & 66.5 & 66.6 & 67.9 & 63.4 & 58.9 & 56.6 & & \\
\hline EA-19 average & 647 & 640 & 669 & 685 & 657 & 696 & 717 & 686 & 698 & 740 & 733 & 714 & 703 & 56 & 4.5 \\
\hline
\end{tabular}

Notes: Total change is the difference between the value for 2017 and the value for 2005. Coeff. Var (\%) stands for the percent Coefficient of Variation measure. All average values are weighted by total banking assets. Source: ECB, own calculations. 


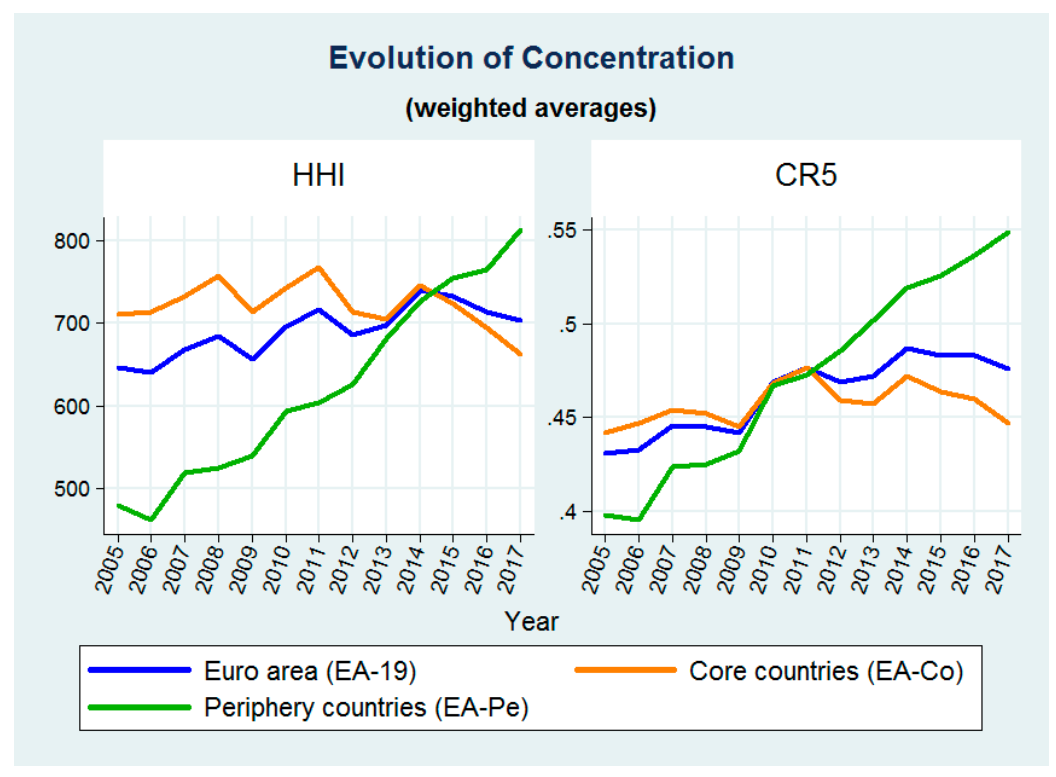

Figure 3. Evolution of bank concentration. Source: ECB, own calculations.

The weighted average of $\mathrm{HHI}$ in EA-19 peaked in 2014, when it started following a decreasing path arriving in 2017 at a value that is 56 points bigger than the HHI value for 2005. The weighted average of HHI in EA-Co reached a peak in 2011, and started declining thereafter, in contrast to the EA-Pe countries whose weighted average of HHI followed an increasing path reaching a peak in 2017.

On the other hand, the row-wise and column-wise coefficients of variation in Table 2 show that there are significant disparities among the $\mathrm{HHI}$ values not only between countries within each year but also between different years for the same country. The biggest decline in HHI values was observed in Belgium, Estonia, and Finland, in contrast to Cyprus and Greece, which presented the biggest increase in $\mathrm{HHI}$ values during the period under examination.

As it is shown in Table 2 and in Figure 2, the disparities in HHI values between EA-Co countries, measured by the coefficient of variation, reached a peak of about $80 \%$ in 2010 . Afterwards they remained at high levels $(74 \%-79 \%)$ until 2015 when they started decreasing, arriving at a minimum of $65 \%$ in 2017. In contrast, the disparities between EA-Pe countries, started increasing in 2011, after having followed a decreasing path since 2005. In 2013, the disparities between EA-Pe countries reached a peak of $50 \%$, staying very close to this level thereafter. The decomposition of the HHI disparities into within-group and between-group components, using the Theil inequality index, is presented in Section 6.3.

\subsection{The Evolution of the CR5 Concentration Ratio}

The CR5 concentration ratio is the sum of the shares of the five largest banks in a banking system. The CR5 evolution for the three country groups under examination is presented in Table 3 and in Figure 3. The weighted average of CR5 in EA-19 peaked in 2014, when it started following a decreasing path arriving in 2017 at a value that is $4.5 \%$ bigger than the CR5 value for 2005 . The weighted average of CR5 in EA-Co reached a peak in 2011, and started declining thereafter, in contrast to EA-Pe whose weighted average of CR5 followed an increasing path since 2007.

On the other hand, the row-wise and column-wise coefficients of variation in Table 3 show that there are significant disparities among the CR5 values not only between countries for each year but also between different years for the same country. The biggest positive evolution for CR5 was observed in Greece, Cyprus, and Spain, in contrast to Belgium and Finland, which presented the biggest decrease in the CR5 value between 2005 and 2017. 
Table 3. Evolution of concentration (market share of the five largest banks, CR5).

\begin{tabular}{|c|c|c|c|c|c|c|c|c|c|c|c|c|c|c|c|}
\hline Country & 2005 & 2006 & 2007 & 2008 & 2009 & 2010 & 2011 & 2012 & 2013 & 2014 & 2015 & 2016 & 2017 & $\begin{array}{c}\text { Total } \\
\text { Change }\end{array}$ & $\begin{array}{l}\text { Coeff. } \\
\text { Var (\%) }\end{array}$ \\
\hline \multicolumn{16}{|c|}{ Euro Area Core Countries (EA-Co) } \\
\hline Austria & 0.450 & 0.438 & 0.428 & 0.390 & 0.372 & 0.359 & 0.384 & 0.365 & 0.367 & 0.368 & 0.358 & 0.345 & 0.361 & -0.089 & 8.8 \\
\hline Belgium & 0.853 & 0.844 & 0.834 & 0.808 & 0.771 & 0.749 & 0.708 & 0.663 & 0.640 & 0.658 & 0.655 & 0.662 & 0.688 & -0.165 & 10.9 \\
\hline Estonia & 0.981 & 0.971 & 0.957 & 0.948 & 0.934 & 0.923 & 0.906 & 0.896 & 0.897 & 0.899 & 0.886 & 0.880 & 0.903 & -0.078 & 3.6 \\
\hline Finland & 0.871 & 0.868 & 0.861 & 0.877 & 0.875 & 0.892 & 0.869 & 0.859 & 0.871 & 0.897 & 0.880 & 0.805 & 0.735 & -0.136 & 5.0 \\
\hline France & 0.519 & 0.523 & 0.518 & 0.512 & 0.472 & 0.474 & 0.483 & 0.446 & 0.467 & 0.476 & 0.472 & 0.460 & 0.454 & -0.065 & 5.5 \\
\hline Germany & 0.216 & 0.220 & 0.220 & 0.227 & 0.250 & 0.326 & 0.335 & 0.330 & 0.306 & 0.321 & 0.306 & 0.314 & 0.297 & 0.081 & 16.8 \\
\hline Latvia & 0.673 & 0.692 & 0.672 & 0.702 & 0.693 & 0.604 & 0.596 & 0.641 & 0.641 & 0.636 & 0.645 & 0.665 & 0.735 & 0.062 & 6.0 \\
\hline Lithuania & 0.806 & 0.825 & 0.809 & 0.813 & 0.805 & 0.788 & 0.847 & 0.836 & 0.871 & 0.857 & 0.868 & 0.871 & 0.901 & 0.095 & 4.0 \\
\hline Luxembourg & 0.345 & 0.315 & 0.306 & 0.297 & 0.293 & 0.311 & 0.312 & 0.331 & 0.337 & 0.320 & 0.313 & 0.276 & 0.262 & -0.083 & 7.5 \\
\hline Netherlands & 0.845 & 0.851 & 0.863 & 0.867 & 0.851 & 0.842 & 0.836 & 0.821 & 0.838 & 0.850 & 0.846 & 0.847 & 0.838 & -0.007 & 1.4 \\
\hline Slovakia & 0.677 & 0.669 & 0.682 & 0.716 & 0.721 & 0.720 & 0.722 & 0.707 & 0.703 & 0.707 & 0.723 & 0.727 & 0.745 & 0.068 & 3.1 \\
\hline Coeff. Var (\%) & 37.3 & 37.9 & 38.1 & 38.8 & 38.7 & 36.5 & 35.4 & 35.4 & 36.3 & 36.4 & 36.9 & 37.5 & 38.3 & & \\
\hline EA-Co average & 0.442 & 0.447 & 0.454 & 0.452 & 0.445 & 0.468 & 0.477 & 0.459 & 0.457 & 0.472 & 0.464 & 0.460 & 0.447 & 0.005 & 2.4 \\
\hline \multicolumn{16}{|c|}{ Euro Area Periphery Countries (EA-Pe) } \\
\hline Cyprus & 0.598 & 0.639 & 0.649 & 0.638 & 0.647 & 0.642 & 0.607 & 0.626 & 0.641 & 0.634 & 0.675 & 0.658 & 0.842 & 0.244 & 9.2 \\
\hline Greece & 0.656 & 0.663 & 0.677 & 0.696 & 0.692 & 0.706 & 0.720 & 0.795 & 0.940 & 0.941 & 0.952 & 0.973 & 0.970 & 0.314 & 16.7 \\
\hline Ireland & 0.478 & 0.490 & 0.504 & 0.503 & 0.526 & 0.499 & 0.467 & 0.464 & 0.478 & 0.476 & 0.459 & 0.443 & 0.455 & -0.023 & 4.9 \\
\hline Italy & 0.268 & 0.262 & 0.331 & 0.312 & 0.310 & 0.398 & 0.395 & 0.397 & 0.396 & 0.410 & 0.410 & 0.430 & 0.434 & 0.166 & 16.6 \\
\hline Malta & 0.753 & 0.709 & 0.702 & 0.728 & 0.728 & 0.713 & 0.720 & 0.744 & 0.765 & 0.815 & 0.813 & 0.803 & 0.809 & 0.056 & 5.6 \\
\hline Portugal & 0.688 & 0.679 & 0.678 & 0.691 & 0.701 & 0.709 & 0.708 & 0.699 & 0.703 & 0.692 & 0.723 & 0.712 & 0.731 & 0.043 & 2.3 \\
\hline Slovenia & 0.630 & 0.620 & 0.595 & 0.591 & 0.597 & 0.593 & 0.593 & 0.584 & 0.571 & 0.556 & 0.592 & 0.610 & 0.615 & -0.015 & 3.3 \\
\hline Spain & 0.420 & 0.404 & 0.410 & 0.424 & 0.433 & 0.443 & 0.481 & 0.514 & 0.544 & 0.583 & 0.602 & 0.618 & 0.637 & 0.217 & 17.3 \\
\hline Coeff. Var (\%) & 28.6 & 28.3 & 24.4 & 25.8 & 25.4 & 21.5 & 21.7 & 23.2 & 27.4 & 27.4 & 27.3 & 27.3 & 27.3 & & \\
\hline EA-Pe average & 0.398 & 0.395 & 0.424 & 0.425 & 0.432 & 0.467 & 0.473 & 0.486 & 0.502 & 0.519 & 0.526 & 0.537 & 0.549 & 0.151 & 11.3 \\
\hline \multicolumn{16}{|c|}{ All Euro Area Countries (EA-19) } \\
\hline Coeff. Var (\%) & 34.7 & 35.1 & 33.8 & 34.5 & 33.9 & 31.2 & 30.5 & 30.4 & 32.0 & 32.0 & 32.3 & 32.6 & 33.1 & & \\
\hline EA-19 average & 0.431 & 0.433 & 0.446 & 0.445 & 0.442 & 0.469 & 0.477 & 0.469 & 0.472 & 0.487 & 0.483 & 0.483 & 0.476 & 0.045 & 4.4 \\
\hline
\end{tabular}

Notes: Total change is the difference between the value for 2017 and the value for 2005. Coeff. Var (\%) stands for the percent Coefficient of Variation measure. All average values are weighted by total banking assets. Source: ECB, own calculations. 
As it is shown in Table 3 and in Figure 2, the disparities in CR5 values between EA-Co countries, measured by the coefficient of variation, reached a peak of about $39 \%$ in 2008 , after a continuous increase from 2005. After a temporary decrease during 2010-2012, they remained at levels ranging between 36 and 38\%. After having followed a decreasing path since 2005, the disparities between EA-Pe countries increased in 2013, remaining afterwards close to $27 \%$. The decomposition of the CR5 disparities into within-group and between-group components, using the Theil inequality index, is presented in Section 6.3 .

\section{Credit Risk in the Euro Area}

Although several years have passed since the onset of the global financial crisis of 2008, many euro area banks still have high levels of non-performing loans (NPLs) on their balance sheets. The non-performing loans to total gross loans ratio (NPL ratio) reached 3.4\% in September 2019 for the euro area as whole (ECB 2020), following a downward trend after 2012, when it reached an all-time high of around $8 \%$. However, despite this positive evolution for the euro area in total, large dispersions remain across euro area countries (ratios between $0.9 \%$ and $37.4 \%$ ). Such a large stock of NPLs puts serious constraints on many banks' lending capacity and their ability to build further capital buffers, thus exerting a strong negative influence on economic growth through the reduction of credit supply.

Bank competition is one of the factors that have been extensively investigated in the past as one of the major determinants of credit risk, as well as of bank risk in general. In a recent study, Karadima and Louri (2019) reached the conclusion that competition exerts a statistically significant and positive impact on NPLs, supporting the "competition-stability" view in banking. This motivated us to extend the scope of the present study, by investigating the evolution and convergence of NPLs in the euro area during the period 2005-2017. The investigation is based on country-level data collected mainly from the World Bank (2019a, 2019b).

The evolution of NPL ratios for the three country groups under examination is presented in Table 4 and in Figure 4. The weighted average of the NPL ratio in EA-19 peaked in 2013, when it started following a decreasing path arriving in 2017 at a value 1.6\% higher than that of 2005. The weighted average of the NPL ratio in EA-Co reached a maximum of 3.4\% in 2009 and 2013, and started declining thereafter, reaching in 2017 a value $0.9 \%$ smaller than that of 2005. In contrast, after a very sharp and continuous increase, which started in 2008, the weighted average of NPL ratio in EA-Pe reached a maximum of $15.6 \%$ in 2014, when it started decreasing arriving in 2017 at a value $8.5 \%$ higher than that of 2005.

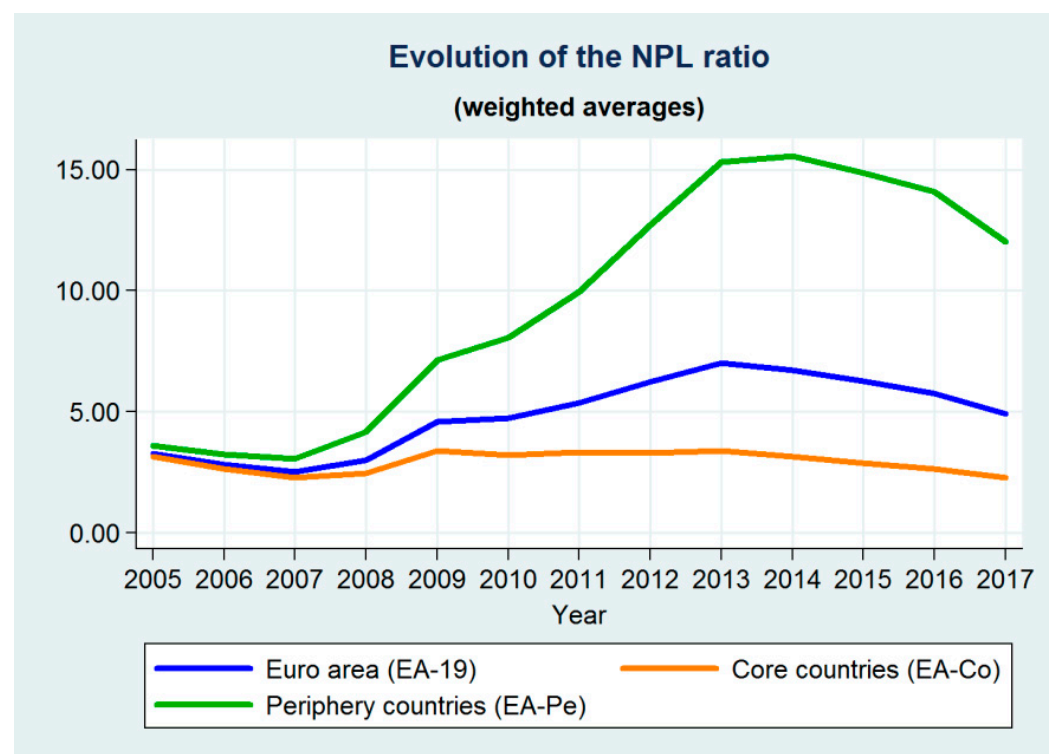

Figure 4. Evolution of the NPL ratio. Source: World Bank, own calculations. 
Table 4. Evolution of credit risk (non-performing loan (NPL) ratio).

\begin{tabular}{|c|c|c|c|c|c|c|c|c|c|c|c|c|c|c|c|}
\hline Country & 2005 & 2006 & 2007 & 2008 & 2009 & 2010 & 2011 & 2012 & 2013 & 2014 & 2015 & 2016 & 2017 & $\begin{array}{l}\text { Total } \\
\text { change }\end{array}$ & $\begin{array}{l}\text { Coeff. } \\
\text { Var }(\%\end{array}$ \\
\hline \multicolumn{16}{|c|}{ Euro area core countries (EA-Co) } \\
\hline Austria & 2.60 & 2.74 & 2.24 & 1.90 & 2.25 & 2.83 & 2.71 & 2.81 & 2.87 & 3.47 & 3.39 & 2.70 & 2.37 & -0.23 & 16.3 \\
\hline Belgium & 2.00 & 1.28 & 1.16 & 1.65 & 3.08 & 2.80 & 3.30 & 3.74 & 4.24 & 4.18 & 3.79 & 3.43 & 2.92 & 0.92 & 36.6 \\
\hline Estonia & 0.20 & 0.20 & 0.50 & 1.94 & 5.20 & 5.38 & 4.05 & 2.62 & 1.47 & 1.39 & 0.98 & 0.87 & 0.70 & 0.50 & 92.6 \\
\hline Finland & 0.30 & 0.20 & 0.30 & 0.40 & 0.60 & 0.60 & 0.50 & 0.50 & 0.67 & 1.30 & 1.34 & 1.52 & 1.67 & 1.37 & 66.7 \\
\hline France & 3.50 & 3.00 & 2.70 & 2.82 & 4.02 & 3.76 & 4.29 & 4.29 & 4.50 & 4.16 & 3.98 & 3.64 & 3.08 & -0.42 & 16.5 \\
\hline Germany & 4.05 & 3.41 & 2.65 & 2.85 & 3.31 & 3.20 & 3.03 & 2.86 & 2.70 & 2.34 & 1.97 & 1.71 & 1.50 & -2.55 & 26.2 \\
\hline Latvia & 0.70 & 0.50 & 0.80 & 2.10 & 14.28 & 15.93 & 14.05 & 8.72 & 6.41 & 4.60 & 4.64 & 6.26 & 5.51 & 4.81 & 82.0 \\
\hline Lithuania & 0.60 & 1.00 & 1.00 & 6.08 & 23.99 & 23.33 & 18.84 & 14.80 & 11.59 & 8.19 & 4.95 & 3.66 & 3.18 & 2.58 & 90.4 \\
\hline Luxembourg & 0.20 & 0.10 & 0.40 & 0.60 & 0.67 & 0.25 & 0.38 & 0.15 & 0.21 & 0.21 & 0.21 & 0.90 & 0.79 & 0.59 & 67.7 \\
\hline Netherlands & 1.20 & 0.80 & 1.50 & 1.68 & 3.20 & 2.83 & 2.71 & 3.10 & 3.23 & 2.98 & 2.71 & 2.54 & 2.31 & 1.11 & 34.2 \\
\hline Slovakia & 5.00 & 3.20 & 2.50 & 2.49 & 5.29 & 5.84 & 5.61 & 5.22 & 5.14 & 5.35 & 4.87 & 4.44 & 3.70 & -1.30 & 25.6 \\
\hline Coeff. Var (\%) & 92.4 & 88.5 & 65.4 & 67.3 & 117.2 & 117.1 & 106.6 & 93.2 & 81.0 & 64.0 & 55.6 & 56.7 & 55.2 & & \\
\hline EA-Co average & 3.15 & 2.63 & 2.28 & 2.45 & 3.38 & 3.20 & 3.32 & 3.30 & 3.38 & 3.14 & 2.88 & 2.62 & 2.28 & -0.87 & 14.4 \\
\hline \multicolumn{16}{|c|}{ Euro area periphery countries (EA-Pe) } \\
\hline Cyprus & 7.10 & 5.40 & 3.40 & 3.59 & 4.51 & 5.82 & 9.99 & 18.37 & 38.56 & 44.97 & 47.75 & 48.68 & 40.17 & 33.07 & 89.5 \\
\hline Greece & 6.30 & 5.40 & 4.60 & 4.67 & 6.95 & 9.12 & 14.43 & 23.27 & 31.90 & 33.78 & 36.65 & 36.30 & 45.57 & 39.27 & 75.7 \\
\hline Ireland & 0.48 & 0.53 & 0.63 & 1.92 & 9.80 & 13.05 & 16.12 & 24.99 & 25.71 & 20.65 & 14.93 & 13.61 & 11.46 & 10.98 & 75.6 \\
\hline Italy & 7.00 & 6.57 & 5.78 & 6.28 & 9.45 & 10.03 & 11.74 & 13.75 & 16.54 & 18.03 & 18.06 & 17.12 & 14.38 & 7.38 & 39.5 \\
\hline Malta & 8.21 & 6.47 & 5.31 & 5.01 & 5.78 & 7.02 & 7.09 & 7.75 & 8.95 & 9.05 & 6.77 & 5.32 & 4.07 & -4.14 & 23.2 \\
\hline Portugal & 1.50 & 1.30 & 2.85 & 3.60 & 5.13 & 5.31 & 7.47 & 9.74 & 10.62 & 11.91 & 17.48 & 17.18 & 13.27 & 11.77 & 67.7 \\
\hline Slovenia & 2.50 & 2.50 & 2.50 & 4.22 & 5.79 & 8.21 & 11.81 & 15.18 & 13.31 & 11.73 & 9.96 & 5.07 & 3.20 & 0.70 & 61.7 \\
\hline Spain & 0.79 & 0.70 & 0.90 & 2.81 & 4.12 & 4.67 & 6.01 & 7.48 & 9.38 & 8.45 & 6.16 & 5.64 & 4.46 & 3.67 & 60.4 \\
\hline Coeff. Var (\%) & 75.9 & 72.5 & 58.9 & 33.7 & 33.3 & 35.4 & 34.2 & 44.7 & 58.4 & 66.2 & 75.5 & 85.5 & 97.0 & & \\
\hline EA-Pe average & 3.58 & 3.22 & 3.05 & 4.15 & 7.14 & 8.07 & 9.95 & 12.71 & 15.32 & 15.56 & 14.86 & 14.08 & 12.03 & 8.45 & 51.6 \\
\hline \multicolumn{16}{|c|}{ All euro area countries (EA-19) } \\
\hline Coeff. Var (\%) & 93.4 & 91.7 & 75.6 & 55.9 & 87.4 & 82.6 & 72.7 & 84.1 & 103.7 & 113.6 & 126.0 & 134.6 & 147.3 & & \\
\hline EA-19 average & 3.27 & 2.80 & 2.51 & 2.98 & 4.59 & 4.72 & 5.35 & 6.23 & 7.02 & 6.72 & 6.26 & 5.76 & 4.90 & 1.63 & 32.0 \\
\hline
\end{tabular}

Notes: Total change is the difference between the value for 2017 and the value for 2005. Coeff. Var (\%) stands for the percent Coefficient of Variation measure. All average values are weighted by total banking assets. Source: World Bank, own calculations. 
On the other hand, the row-wise and column-wise coefficients of variation in Table 4 show that there are significant disparities among the NPL ratios not only between countries within each year but also between different years for the same country. The biggest decline in NPL ratio values was observed in Germany and Malta, in contrast to Cyprus and Greece, which presented the biggest increase in NPL ratios during the period under examination.

After having followed a decreasing path until 2008, as it is shown in Table 4 and Figure 2, the disparities between EA-Co countries, measured by the coefficient of variation, increased sharply in 2009 to a level of about $117 \%$. They started decreasing thereafter, arriving a minimum of $55 \%$ in 2017 ; thus, presenting a clear tendency to converge to lower levels. After having followed a decreasing path until 2011, in 2012 the disparities between EA-Pe countries started increasing continuously, arriving at an all-time peak of $97 \%$ in 2017; thus, not showing, in contrast to EA-Co, any sign of convergence to lower levels. By employing the Theil inequality index (see Section 6.4), more information on which part of the disparities is due to differences inside each group (within-group inequality), and which part comes from differences between these two groups (between-group inequality) is provided.

\section{Theil Inequality for Bank Competition, Concentration, and Credit Risk}

\subsection{Theil Inequality Index}

An inequality index that belongs to the entropy class has the following general form:

$$
G E(\alpha)=\frac{1}{n\left(a^{2}-a\right)} \sum_{i=1}^{n}\left[\left(\frac{y_{i}}{\bar{y}}\right)^{\alpha}-1\right]
$$

where $n$ is the size of the sample, $y_{i}$ is the $i$-th observation and $\bar{y}$ is the mean value of the sample. The parameter $\alpha$ represents the weight given to distances between values at different parts of the distribution. For smaller values of $\alpha, G E(\alpha)$ is more sensitive to changes in the bottom tail of the distribution. For higher values of $\alpha, G E(\alpha)$ is more sensitive to changes in the upper tail of the distribution. The most commonly used values of $\alpha$ are $-1,0,1$ and 2 . The most well-known member of the entropy class of inequality indices is the GE(1) index, called Theil index $(T)$, by the name of Henri Theil who introduced it in 1967. All the members of the entropy class of inequality indices have the advantage of being perfectly decomposable (i.e., with a zero residual part).

Following Fernandez de Guevara et al. (2007), the Theil index for bank market power can be calculated from Equation (11):

$$
T=\sum_{g=1}^{G} s h_{g} T_{w, g}+T_{b}
$$

where $T$ is the total market power inequality, $G$ is the number of observation groups in the sample, shg is the share in the sample (in terms of total assets) of a group $g, T_{w, g}$ is the within-group inequality in group $g$ and $T_{b}$ is the between-group inequality.

The within-group inequality in group $g$ is defined by Equation (12):

$$
T_{w, g}=-\sum_{i=1}^{N_{g}}\left(\frac{s h_{i}}{s h_{g}}\right) \ln \left(\frac{x_{i}}{\mu_{g}}\right)
$$

where $N_{g}$ is the number of entities (e.g., countries or banks) in group $g, s h_{i}$ is the share in the sample (in terms of total assets) of an entity $i$ belonging to group $g$ and $\mu_{g}$ is the weighted average of the Lerner index of entities belonging to group $g$.

The between-group inequality is defined by Equation (13): 


$$
T_{b}=-\sum_{g=1}^{G} \operatorname{sh} g \ln \left(\frac{\mu_{g}}{\mu}\right)
$$

where $\mu$ is the weighted average of the Lerner index (variable $x_{i}$ ) in the sample.

\subsection{Theil Inequality for Market Power}

The results from the calculation of the total Theil inequality index for the Lerner index of market power and its within-group and between-group components are presented in Table 5, as well as in Figures 5 and 6.

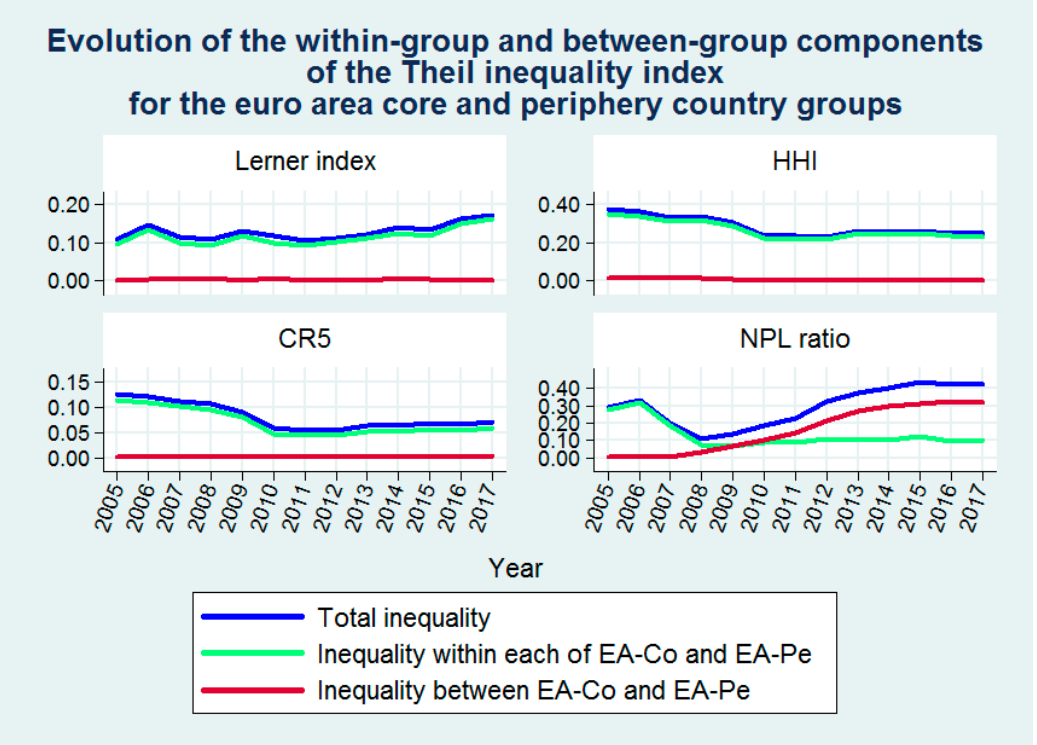

Figure 5. Evolution of the within-group and between-group components of the Theil inequality index for the euro area core and periphery country groups. Source: BankScope database, ECB, World Bank, own calculations.

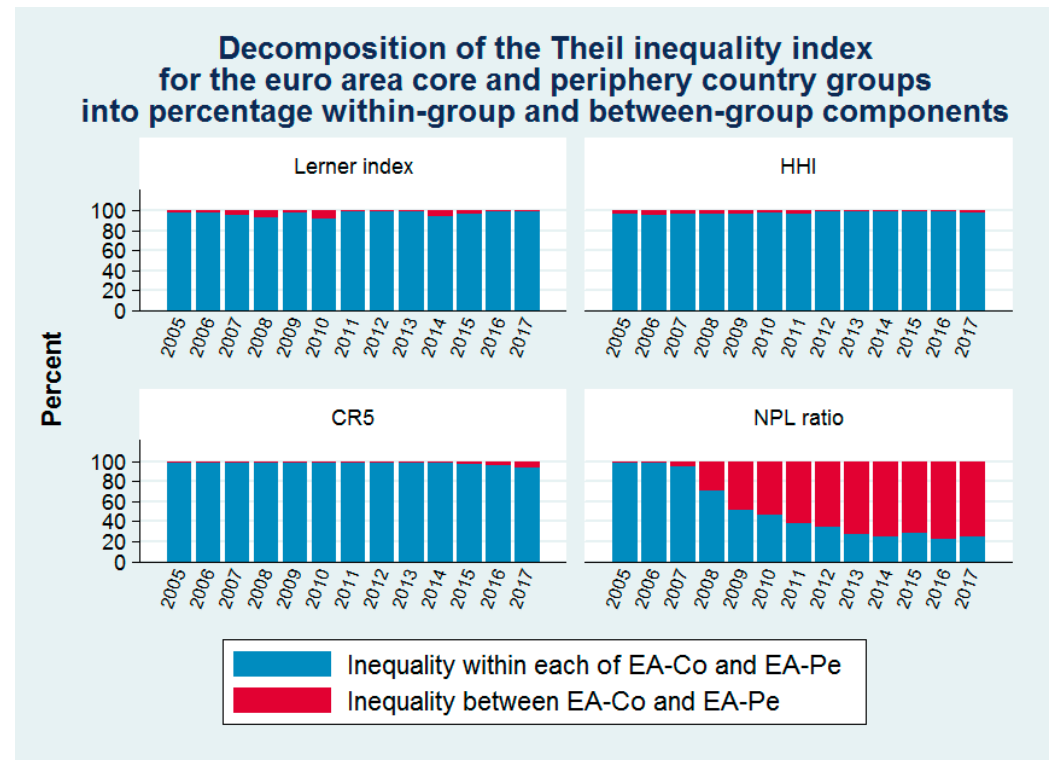

Figure 6. Decomposition of the Theil inequality index for the euro area core and periphery country groups into percentage within-group and between-group components. Source: BankScope database, ECB, World Bank, own calculations. 
Table 5. Evolution and decomposition of the Theil inequality index for the euro area core and periphery country groups into within-group and between-group components.

\begin{tabular}{|c|c|c|c|c|c|c|c|c|c|c|c|c|}
\hline \multirow{3}{*}{ Year } & \multicolumn{3}{|c|}{ Market Power (Lerner Index) } & \multicolumn{3}{|c|}{ Concentration (HHI) } & \multicolumn{3}{|c|}{ Concentration (CR5) } & \multicolumn{3}{|c|}{ Credit Risk (NPL Ratio) } \\
\hline & \multicolumn{3}{|c|}{ Inequality } & \multicolumn{3}{|c|}{ Inequality } & \multicolumn{3}{|c|}{ Inequality } & \multicolumn{3}{|c|}{ Inequality } \\
\hline & Total & $\begin{array}{l}\text { Within- } \\
\text { Group }\end{array}$ & $\begin{array}{l}\text { Between- } \\
\text { Group }\end{array}$ & Total & $\begin{array}{l}\text { Within- } \\
\text { Group }\end{array}$ & $\begin{array}{l}\text { Between- } \\
\text { Group }\end{array}$ & Total & $\begin{array}{l}\text { Within- } \\
\text { Group }\end{array}$ & $\begin{array}{l}\text { Between- } \\
\text { Group }\end{array}$ & Total & $\begin{array}{l}\text { Within- } \\
\text { Group }\end{array}$ & $\begin{array}{c}\text { Between- } \\
\text { Group }\end{array}$ \\
\hline 2005 & 0.099 & $\begin{array}{l}0.097 \\
(98 \%)\end{array}$ & $\begin{array}{l}0.002 \\
(2 \%)\end{array}$ & 0.365 & $\begin{array}{l}0.350 \\
(96 \%)\end{array}$ & $\begin{array}{l}0.015 \\
(4 \%)\end{array}$ & 0.116 & $\begin{array}{l}0.115 \\
(99 \%)\end{array}$ & $\begin{array}{l}0.001 \\
(1 \%) \\
\end{array}$ & 0.280 & $\begin{array}{l}0.278 \\
(99 \%)\end{array}$ & $\begin{array}{l}0.002 \\
(1 \%)\end{array}$ \\
\hline 2006 & 0.136 & $\begin{array}{l}0.133 \\
(98 \%)\end{array}$ & $\begin{array}{l}0.003 \\
(2 \%)\end{array}$ & 0.354 & $\begin{array}{l}0.336 \\
(95 \%)\end{array}$ & $\begin{array}{l}0.018 \\
(5 \%)\end{array}$ & 0.112 & $\begin{array}{l}0.110 \\
(98 \%)\end{array}$ & $\begin{array}{l}0.002 \\
(2 \%)\end{array}$ & 0.322 & $\begin{array}{l}0.318 \\
(99 \%)\end{array}$ & $\begin{array}{l}0.004 \\
(1 \%)\end{array}$ \\
\hline 2007 & 0.105 & $\begin{array}{l}0.100 \\
(95 \%)\end{array}$ & $\begin{array}{l}0.005 \\
(5 \%)\end{array}$ & 0.323 & $\begin{array}{l}0.311 \\
(96 \%)\end{array}$ & $\begin{array}{l}0.012 \\
(4 \%)\end{array}$ & 0.102 & $\begin{array}{l}0.101 \\
(99 \%)\end{array}$ & $\begin{array}{l}0.001 \\
(1 \%)\end{array}$ & 0.194 & $\begin{array}{l}0.185 \\
(95 \%)\end{array}$ & $\begin{array}{l}0.009 \\
(5 \%)\end{array}$ \\
\hline 2008 & 0.099 & $\begin{array}{l}0.092 \\
(93 \%)\end{array}$ & $\begin{array}{l}0.007 \\
(7 \%)\end{array}$ & 0.331 & $\begin{array}{l}0.318 \\
(96 \%)\end{array}$ & $\begin{array}{l}0.013 \\
(4 \%)\end{array}$ & 0.097 & $\begin{array}{l}0.096 \\
(99 \%)\end{array}$ & $\begin{array}{l}0.001 \\
(1 \%)\end{array}$ & 0.108 & $\begin{array}{l}0.077 \\
(71 \%)\end{array}$ & $\begin{array}{l}0.031 \\
(29 \%)\end{array}$ \\
\hline 2009 & 0.121 & $\begin{array}{l}0.119 \\
(98 \%)\end{array}$ & $\begin{array}{l}0.002 \\
(2 \%)\end{array}$ & 0.299 & $\begin{array}{l}0.291 \\
(97 \%)\end{array}$ & $\begin{array}{l}0.008 \\
(3 \%)\end{array}$ & 0.081 & $\begin{array}{l}0.080 \\
(99 \%)\end{array}$ & $\begin{array}{l}0.001 \\
(1 \%)\end{array}$ & 0.135 & $\begin{array}{l}0.069 \\
(51 \%)\end{array}$ & $\begin{array}{l}0.066 \\
(49 \%)\end{array}$ \\
\hline 2010 & 0.110 & $\begin{array}{l}0.101 \\
(92 \%)\end{array}$ & $\begin{array}{l}0.009 \\
(8 \%)\end{array}$ & 0.229 & $\begin{array}{l}0.224 \\
(98 \%)\end{array}$ & $\begin{array}{l}0.005 \\
(2 \%)\end{array}$ & 0.049 & $\begin{array}{l}0.048 \\
(98 \%)\end{array}$ & $\begin{array}{l}0.001 \\
(2 \%)\end{array}$ & 0.187 & $\begin{array}{l}0.087 \\
(47 \%)\end{array}$ & $\begin{array}{l}0.100 \\
(53 \%)\end{array}$ \\
\hline 2011 & 0.095 & $\begin{array}{l}0.094 \\
(99 \%)\end{array}$ & $\begin{array}{l}0.001 \\
(1 \%)\end{array}$ & 0.227 & $\begin{array}{l}0.221 \\
(97 \%)\end{array}$ & $\begin{array}{l}0.006 \\
(3 \%)\end{array}$ & 0.045 & $\begin{array}{l}0.044 \\
(98 \%)\end{array}$ & $\begin{array}{l}0.001 \\
(2 \%)\end{array}$ & 0.229 & $\begin{array}{l}0.088 \\
(38 \%)\end{array}$ & $\begin{array}{l}0.141 \\
(62 \%)\end{array}$ \\
\hline 2012 & 0.103 & $\begin{array}{l}0.102 \\
(99 \%)\end{array}$ & $\begin{array}{l}0.001 \\
(1 \%)\end{array}$ & 0.218 & $\begin{array}{l}0.216 \\
(99 \%)\end{array}$ & $\begin{array}{l}0.002 \\
(1 \%)\end{array}$ & 0.045 & $\begin{array}{l}0.044 \\
(98 \%)\end{array}$ & $\begin{array}{l}0.001 \\
(2 \%)\end{array}$ & 0.325 & $\begin{array}{l}0.110 \\
(34 \%)\end{array}$ & $\begin{array}{l}0.215 \\
(66 \%)\end{array}$ \\
\hline 2013 & 0.112 & $\begin{array}{l}0.111 \\
(99 \%)\end{array}$ & $\begin{array}{l}0.001 \\
(1 \%)\end{array}$ & 0.249 & $\begin{array}{l}0.247 \\
(99 \%)\end{array}$ & $\begin{array}{l}0.002 \\
(1 \%)\end{array}$ & 0.054 & $\begin{array}{l}0.053 \\
(98 \%)\end{array}$ & $\begin{array}{l}0.001 \\
(2 \%)\end{array}$ & 0.372 & $\begin{array}{l}0.102 \\
(27 \%)\end{array}$ & $\begin{array}{l}0.270 \\
(73 \%)\end{array}$ \\
\hline 2014 & 0.134 & $\begin{array}{l}0.126 \\
(94 \%)\end{array}$ & $\begin{array}{l}0.008 \\
(6 \%)\end{array}$ & 0.243 & $\begin{array}{c}0.241 \\
(99 \%)\end{array}$ & $\begin{array}{l}0.002 \\
(1 \%)\end{array}$ & 0.053 & $\begin{array}{l}0.052 \\
(98 \%)\end{array}$ & $\begin{array}{l}0.001 \\
(2 \%)\end{array}$ & 0.400 & $\begin{array}{l}0.100 \\
(25 \%)\end{array}$ & $\begin{array}{l}0.300 \\
(75 \%)\end{array}$ \\
\hline 2015 & 0.124 & $\begin{array}{l}0.119 \\
(96 \%)\end{array}$ & $\begin{array}{l}0.005 \\
(4 \%)\end{array}$ & 0.249 & $\begin{array}{l}0.247 \\
(99 \%)\end{array}$ & $\begin{array}{l}0.002 \\
(1 \%)\end{array}$ & 0.059 & $\begin{array}{l}0.057 \\
(97 \%)\end{array}$ & $\begin{array}{l}0.002 \\
(3 \%)\end{array}$ & 0.437 & $\begin{array}{l}0.123 \\
(28 \%)\end{array}$ & $\begin{array}{l}0.314 \\
(72 \%)\end{array}$ \\
\hline 2016 & 0.153 & $\begin{array}{l}0.152 \\
(99 \%)\end{array}$ & $\begin{array}{l}0.001 \\
(1 \%)\end{array}$ & 0.237 & $\begin{array}{l}0.235 \\
(99 \%)\end{array}$ & $\begin{array}{l}0.002 \\
(1 \%)\end{array}$ & 0.057 & $\begin{array}{l}0.055 \\
(96 \%)\end{array}$ & $\begin{array}{l}0.002 \\
(4 \%)\end{array}$ & 0.423 & $\begin{array}{l}0.097 \\
(23 \%)\end{array}$ & $\begin{array}{l}0.326 \\
(77 \%)\end{array}$ \\
\hline 2017 & 0.164 & $\begin{array}{l}0.162 \\
(99 \%)\end{array}$ & $\begin{array}{l}0.002 \\
(1 \%)\end{array}$ & 0.236 & $\begin{array}{l}0.232 \\
(98 \%)\end{array}$ & $\begin{array}{l}0.004 \\
(2 \%)\end{array}$ & 0.062 & $\begin{array}{l}0.058 \\
(94 \%)\end{array}$ & $\begin{array}{l}0.004 \\
(6 \%)\end{array}$ & 0.421 & $\begin{array}{c}0.104 \\
(25 \%)\end{array}$ & $\begin{array}{l}0.317 \\
(75 \%)\end{array}$ \\
\hline Total change & 0.065 & 0.065 & 0.000 & -0.129 & -0.118 & -0.011 & -0.054 & -0.057 & 0.003 & 0.141 & -0.174 & 0.315 \\
\hline
\end{tabular}

Notes: Total change is the difference between the value for 2017 and the value for 2005. The figures in parentheses denote percentages of within-group and between-group inequality over total inequality. Source: BankScope database, ECB, World Bank, own calculations. 
As it is shown in Table 5, as well as in Figures 5 and 6, the disparities in market power are due, almost exclusively, to differences inside each group (EA-Co or EA-Pe). The differences between the EA-Co and EA-Pe are negligible. This evolution suggests that there is a clear convergence between the EA-Co and EA-Pe country groups with respect to competition, as measured by the Lerner index of market power. In addition, it is also clear that we need higher granularity, which can be obtained by investigating whether differences in market power stem from inequalities between different countries (between-country inequality) or from inequalities between banks in a given country (within-country inequality). This desired level of granularity can be obtained by the calculation of a Theil inequality index and its decomposition into within-country and between-country components.

The results from the calculation of the total Theil inequality index and its within-country and between-country components are presented in Table $6^{5}$, as well as in Figures 7 and 8 . Figure 7 shows that in 2008 the level of total inequality in bank market power in EA-19 was close to its 2005 level, after a sharp increase of the between-country inequality in 2006. The increase of the Theil inequality index in 2009 indicates that the financial crisis reversed the progress towards lower disparities across countries, suggested by the lower values of the between-country component in the period 2007-2008. In 2011, total inequality was close to its 2008 level, since an increase in within-country inequality in 2011 was accompanied by a decrease in between-country inequality in that year. Total inequality started increasing in 2012, mainly due to an increase in its within-country component, reaching a peak in 2017. The persistence of significant within-country inequalities in market power has also been shown by Cruz-Garcia et al. (2017), who investigate the impact of financial market integration on the evolution of disparities among European banks' market power using bank-specific data for the EA-12 countries over the period 2000-2014.

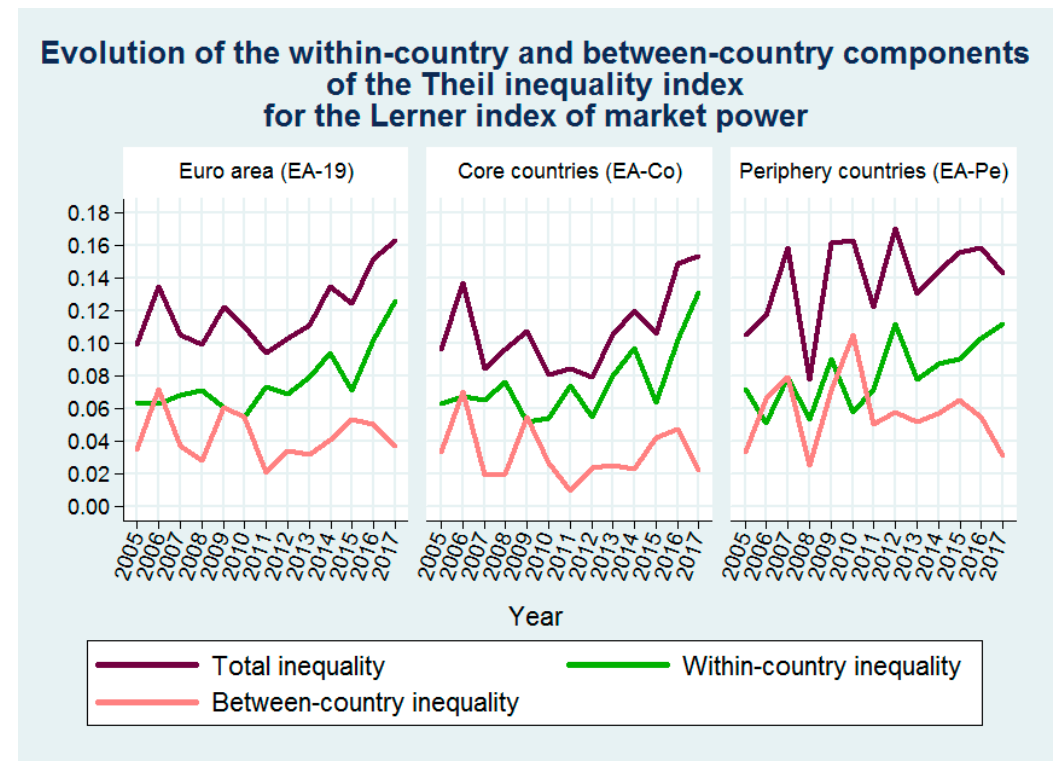

Figure 7. Evolution of the within-country and between-country components of the Theil inequality index for the Lerner index of market power. Source: BankScope database, own calculations.

The level of total inequality in bank market power in periphery countries was generally higher, presenting also more fluctuations than that of the core countries during almost all years of the period under study, mainly due to the higher between-country inequality among periphery countries.

5 It should be noted that some expected minor differences (at the third decimal place) in total inequality between Tables 5 and 6 are due to different data grouping (19 countries vs EA-Co/EA-Pe) and weighting. 
Table 6. Evolution and decomposition of the Theil inequality index for the Lerner index of market power into within-country and between-country components

\begin{tabular}{|c|c|c|c|c|c|c|c|c|c|}
\hline \multirow{3}{*}{ Year } & \multicolumn{3}{|c|}{ Euro Area (EA-19) } & \multicolumn{3}{|c|}{ Core Countries (EA-Co) } & \multicolumn{3}{|c|}{ Periphery Countries (EA-Pe) } \\
\hline & \multicolumn{3}{|c|}{ Inequality } & \multicolumn{3}{|c|}{ Inequality } & \multicolumn{3}{|c|}{ Inequality } \\
\hline & Total & Within-Country & Between-Country & Total & Within-Country & Between-Country & Total & Within-Country & Between-Country \\
\hline 2005 & 0.099 & $\begin{array}{l}0.064 \\
(65 \%) \\
\end{array}$ & $\begin{array}{l}0.035 \\
(35 \%) \\
\end{array}$ & 0.096 & $\begin{array}{l}0.063 \\
(66 \%) \\
\end{array}$ & $\begin{array}{l}0.033 \\
(34 \%) \\
\end{array}$ & 0.105 & $\begin{array}{c}0.072 \\
(69 \%) \\
\end{array}$ & $\begin{array}{l}0.033 \\
(31 \%) \\
\end{array}$ \\
\hline 2006 & 0.135 & $\begin{array}{l}0.063 \\
(47 \%) \\
\end{array}$ & $\begin{array}{c}0.072 \\
(53 \%) \\
\end{array}$ & 0.137 & $\begin{array}{l}0.067 \\
(49 \%) \\
\end{array}$ & $\begin{array}{l}0.070 \\
(51 \%) \\
\end{array}$ & 0.117 & $\begin{array}{l}0.051 \\
(44 \%) \\
\end{array}$ & $\begin{array}{l}0.066 \\
(56 \%) \\
\end{array}$ \\
\hline 2007 & 0.105 & $\begin{array}{l}0.068 \\
(65 \%) \\
\end{array}$ & $\begin{array}{r}0.037 \\
(35 \%) \\
\end{array}$ & 0.084 & $\begin{array}{r}0.065 \\
(77 \%) \\
\end{array}$ & $\begin{array}{r}0.019 \\
(23 \%) \\
\end{array}$ & 0.158 & $\begin{array}{l}0.079 \\
(50 \%) \\
\end{array}$ & $\begin{array}{r}0.079 \\
(50 \%) \\
\end{array}$ \\
\hline 2008 & 0.099 & $\begin{array}{c}0.071 \\
(72 \%)\end{array}$ & $\begin{array}{c}0.028 \\
(28 \%)\end{array}$ & 0.096 & $\begin{array}{l}0.076 \\
(79 \%)\end{array}$ & $\begin{array}{l}0.020 \\
(21 \%)\end{array}$ & 0.078 & $\begin{array}{c}0.053 \\
(68 \%)\end{array}$ & $\begin{array}{l}0.025 \\
(32 \%)\end{array}$ \\
\hline 2009 & 0.122 & $\begin{array}{l}0.061 \\
(50 \%) \\
\end{array}$ & $\begin{array}{c}0.061 \\
(50 \%) \\
\end{array}$ & 0.107 & $\begin{array}{l}0.052 \\
(49 \%) \\
\end{array}$ & $\begin{array}{l}0.055 \\
(51 \%) \\
\end{array}$ & 0.161 & $\begin{array}{l}0.090 \\
(56 \%) \\
\end{array}$ & $\begin{array}{l}0.071 \\
(44 \%) \\
\end{array}$ \\
\hline 2010 & 0.110 & $\begin{array}{l}0.055 \\
(50 \%) \\
\end{array}$ & $\begin{array}{l}0.055 \\
(50 \%) \\
\end{array}$ & 0.081 & $\begin{array}{l}0.054 \\
(67 \%) \\
\end{array}$ & $\begin{array}{r}0.027 \\
(33 \%) \\
\end{array}$ & 0.163 & $\begin{array}{l}0.058 \\
(36 \%) \\
\end{array}$ & $\begin{array}{l}0.105 \\
(64 \%) \\
\end{array}$ \\
\hline 2011 & 0.094 & $\begin{array}{l}0.073 \\
(78 \%) \\
\end{array}$ & $\begin{array}{r}0.021 \\
(22 \%) \\
\end{array}$ & 0.084 & $\begin{array}{r}0.074 \\
(88 \%) \\
\end{array}$ & $\begin{array}{r}0.010 \\
(12 \%) \\
\end{array}$ & 0.122 & $\begin{array}{l}0.072 \\
(59 \%) \\
\end{array}$ & $\begin{array}{l}0.050 \\
(41 \%) \\
\end{array}$ \\
\hline 2012 & 0.103 & $\begin{array}{l}0.069 \\
(67 \%) \\
\end{array}$ & $\begin{array}{c}0.034 \\
(33 \%) \\
\end{array}$ & 0.079 & $\begin{array}{l}0.055 \\
(70 \%) \\
\end{array}$ & $\begin{array}{c}0.024 \\
(30 \%) \\
\end{array}$ & 0.170 & $\begin{array}{l}0.112 \\
(66 \%) \\
\end{array}$ & $\begin{array}{l}0.058 \\
(34 \%) \\
\end{array}$ \\
\hline 2013 & 0.111 & $\begin{array}{c}0.079 \\
(71 \%)\end{array}$ & $\begin{array}{l}0.032 \\
(29 \%)\end{array}$ & 0.105 & $\begin{array}{c}0.080 \\
(76 \%)\end{array}$ & $\begin{array}{l}0.025 \\
(24 \%)\end{array}$ & 0.130 & $\begin{array}{l}0.078 \\
(60 \%)\end{array}$ & $\begin{array}{l}0.052 \\
(40 \%)\end{array}$ \\
\hline 2014 & 0.135 & $\begin{array}{l}0.094 \\
(70 \%) \\
\end{array}$ & $\begin{array}{l}0.041 \\
(30 \%) \\
\end{array}$ & 0.120 & $\begin{array}{r}0.097 \\
(81 \%) \\
\end{array}$ & $\begin{array}{r}0.023 \\
(19 \%) \\
\end{array}$ & 0.144 & $\begin{array}{l}0.087 \\
(61 \%) \\
\end{array}$ & $\begin{array}{r}0.057 \\
(39 \%) \\
\end{array}$ \\
\hline 2015 & 0.124 & $\begin{array}{r}0.071 \\
(57 \%) \\
\end{array}$ & $\begin{array}{r}0.053 \\
(43 \%) \\
\end{array}$ & 0.106 & $\begin{array}{l}0.064 \\
(60 \%) \\
\end{array}$ & $\begin{array}{l}0.042 \\
(40 \%) \\
\end{array}$ & 0.155 & $\begin{array}{l}0.090 \\
(58 \%) \\
\end{array}$ & $\begin{array}{l}0.065 \\
(42 \%) \\
\end{array}$ \\
\hline 2016 & 0.152 & $\begin{array}{c}0.102 \\
(67 \%)\end{array}$ & $\begin{array}{l}0.050 \\
(33 \%)\end{array}$ & 0.149 & $\begin{array}{c}0.102 \\
(68 \%)\end{array}$ & $\begin{array}{c}0.047 \\
(32 \%)\end{array}$ & 0.158 & $\begin{array}{c}0.103 \\
(65 \%)\end{array}$ & $\begin{array}{l}0.055 \\
(35 \%)\end{array}$ \\
\hline 2017 & 0.163 & $\begin{array}{l}0.126 \\
(77 \%) \\
\end{array}$ & $\begin{array}{l}0.037 \\
(23 \%) \\
\end{array}$ & 0.153 & $\begin{array}{l}0.131 \\
(86 \%) \\
\end{array}$ & $\begin{array}{l}0.022 \\
(14 \%) \\
\end{array}$ & 0.143 & $\begin{array}{l}0.112 \\
(78 \%) \\
\end{array}$ & $\begin{array}{l}0.031 \\
(22 \%) \\
\end{array}$ \\
\hline Total change & 0.064 & 0.062 & 0.002 & 0.057 & 0.068 & -0.011 & 0.038 & 0.040 & -0.002 \\
\hline
\end{tabular}

Notes: Total change is the difference between the value for 2017 and the value for 2005 . The figures in parentheses denote percentages of within-country and between-country inequality over total inequality. Source: BankScope database, own calculations. 


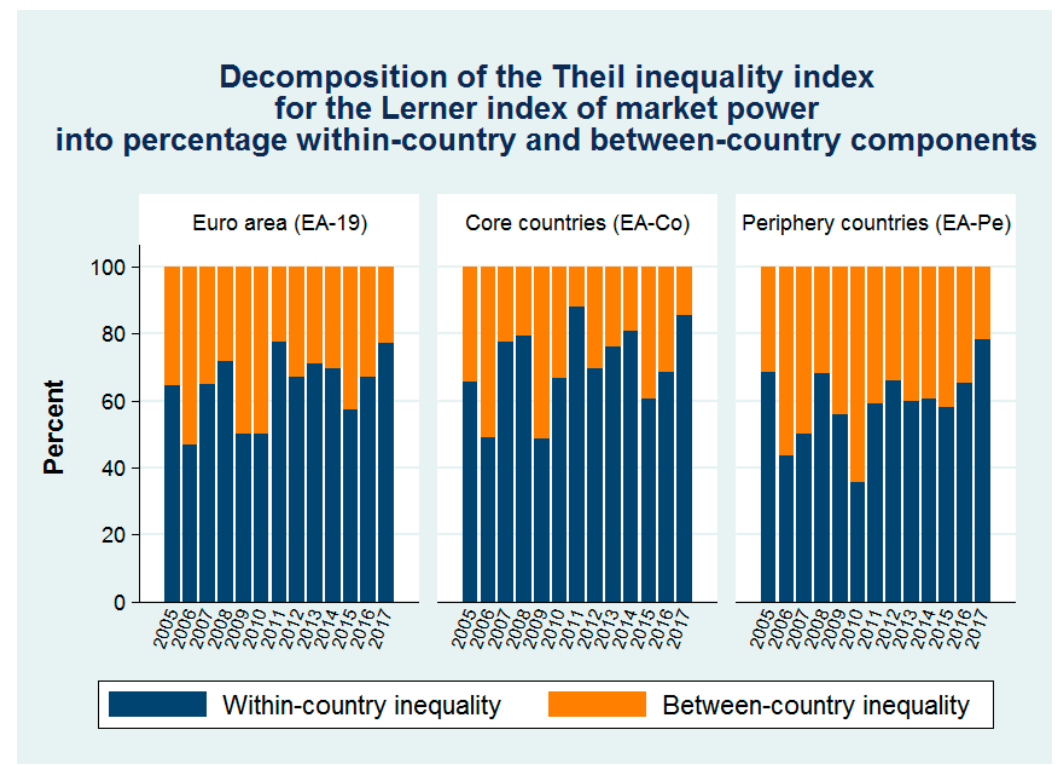

Figure 8. Decomposition of the Theil inequality index for the Lerner index of market power into percentage within-country and between-country components. Source: BankScope database, own calculations.

As shown in Figure 8, from 2011 to 2017 the between-country inequality was generally much smaller than the within-country inequality across all the three country groups under examination, indicating a decrease in fragmentation in the euro area with respect to market power.

The values of the Lerner index and the Theil inequality index, presented in Tables 1 and 6, respectively, could be biased due to the unbalanced nature of the underlying panel dataset, so we also considered a fully balanced subset of the unbalanced dataset. After the deletion of countries with less than five banks per year, the balanced subset contains 7605 observations from 585 banks from nine euro area countries (Austria, Belgium, France, Germany, Italy, Latvia, Lithuania, Luxembourg, and Slovakia). The results obtained for this group of nine countries were generally in line with the results obtained for EA-19.

\subsection{Theil Inequality for Concentration}

The results from the calculation of the total Theil inequality index for HHI and its within-group and between-group components are presented in Table 5, as well as in Figures 5 and 6 . As it is shown in Table 5, as well as in Figures 5 and 6, the disparities in HHI values are due, almost exclusively, to differences inside each group (EA-Co or EA-Pe). This evolution suggests that there is a clear convergence between the EA-Co and EA-Pe country groups with respect to concentration, as measured by the HHI structural measure. In contrast to the case of the Lerner index, the lack of availability of the bank-level underlying determinants of $\mathrm{HHI}$ did not let us to go deeper in order to investigate whether the above-described differences stem from inequalities between different countries (between-country inequality) or from inequalities between banks in a given country (within-country inequality).

The results from the calculation of the total Theil inequality index for CR5 and its within-group and between-group components are presented in Table 5, as well as in Figures 5 and 6. As it is shown in Table 5, as well as in Figures 5 and 6, the disparities in CR5 values are due, almost exclusively, to differences inside each group (EA-Co or EA-Pe). This evolution suggests that there is a clear convergence between the EA-Co and EA-Pe country groups with respect to concentration, as measured by the CR5 structural measure. The lack of availability of the bank-level underlying determinants of CR5 did not let us to go deeper in order to investigate whether these differences stem from inequalities between different countries (between-country inequality) or from inequalities between banks in a given country (within-country inequality). 


\subsection{Theil Inequality for Credit Risk (NPL Ratio)}

The results from the calculation of the total Theil inequality index for the NPL ratio and its within-group and between-group components are presented in Table 5, as well as in Figures 5 and 6 . As it is shown in Table 5, as well as in Figures 5 and 6, the between-group component of the Theil index (disparities due to differences between EA-Co and EA-Pe) presented a sharp increase in 2008, when it started following a continuously increasing path until 2013, afterwards fluctuating slightly to the end of 2017. This evolution shows that there is a clear divergence between the EA-Co and EA-Pe country groups with respect to credit risk, as measured by the NPL ratio. The lack of availability of the underlying bank-level NPL data did not let us to go deeper in order to investigate whether the above-described differences stem from inequalities between different countries (between-country inequality) or from inequalities between banks in a given country (within-country inequality).

\section{Convergence Analysis}

The evolution of the coefficient of variation, presented in Table 1 and in Figure 2, provides useful information about changes of inequality in Lerner index values across countries and/or years. However, the visual inspection of these changes cannot always provide safe results regarding the existence of convergence or divergence in terms of the Lerner index across euro area countries during a given period, especially when the Lerner index has presented significant ups and downs along this period. The same situation holds in the case of the two concentration measures (HHI/CR5) and the NPL ratio.

To overcome these problems, we employ two concepts of convergence, namely $\beta$-convergence and $\sigma$-convergence (Barro and Sala-i-Martin 1991), which have been prevailing for many years in the growth literature. $\beta$-convergence applies if poor countries tend to catch up with rich ones in terms of per capita income or product levels. In the case of competition, $\beta$-convergence would apply if countries with lower levels of competition were found to tend to catch up with countries with higher levels of competition. On the other hand, $\sigma$-convergence applies if the dispersion of per capita income or product across countries declines over time. The existence of $\beta$-convergence is a necessary but not sufficient condition for $\sigma$-convergence. Regarding competition, $\sigma$-convergence would apply if the dispersion of competition levels across countries showed a tendency to decline over time.

In the case of competition, the $\beta$-convergence test is performed through the estimation of Equation (14).

$$
\ln \left(\frac{C_{i t}}{C_{i, t-1}}\right)=\alpha+\beta \ln C_{i, t-1}+\sum \text { Country }_{i}+\varepsilon_{i t}
$$

where $C_{i t}$ is the level of competition, as expressed by the (inverse of) the Lerner index, in country $i$ in year $t, \alpha$ and $\beta$ are parameters to be estimated, Country $y_{i}$ are dummy variables to control for possible country effects, and $\varepsilon_{i t}$ is a random error term. There is $\beta$-convergence when the coefficient $\beta$ in (14) is statistically significant and negative. A higher absolute value of the coefficient $\beta$ corresponds to a greater tendency towards $\beta$-convergence.

Following Lapteacru (2018), the $\sigma$-convergence test is performed through the estimation of Equation (15):

$$
D_{i t}=\alpha+\sigma T+\sum \text { Country }_{i}+\varepsilon_{i t}
$$

where $D_{i t}$ is the absolute value of the difference between the competition in country $i$ in year $t$ and the average competition in year $t, T$ is a time trend, $\alpha$ and $\sigma$ are parameters to be estimated, Country are dummy variables to control for possible country effects, and $\varepsilon_{i t}$ is a random error term. There is $\sigma$-convergence when the coefficient $\sigma$ in (15) is statistically significant and negative. A higher absolute value of the coefficient $\sigma$ corresponds to a greater tendency towards $\sigma$-convergence.

The estimation of Equations (14) and (15) is performed by applying Ordinary Least Squares (OLS) regressions. A same type convergence analysis, as that described for competition, was also performed for concentration (HHI/CR5) and NPLs. The results, which are presented in Table 7, cover the total period under study (i.e., 2005-2017), as well as two important sub-periods: (a) the period 2008-2012, 
which includes the years of the financial and debt crisis in the euro area, and (b) the period 2013-2017. This division was based on the evolution of financial integration in the euro area. As Berenberg-Gossler and Enderlein (2016) note, financial integration reached a minimum in July 2012. After the ECB announcement of the OMT program on 26 July, 2012, there was a gradual, but often fragile, decline of financial market fragmentation across all markets. It should also be noted that the sub-period 2005-2007 was not included in the regression analysis, due to its limited time coverage that might possibly provide biased estimations.

Table 7. Regression results for $\beta$-convergence and $\sigma$-convergence.

\begin{tabular}{|c|c|c|c|c|c|c|c|}
\hline \multirow{2}{*}{ Variable } & \multirow{2}{*}{ Period } & \multicolumn{2}{|c|}{ EA-19 } & \multicolumn{2}{|c|}{ EA-Co } & \multicolumn{2}{|c|}{ EA-Pe } \\
\hline & & $\beta$ & $\sigma$ & $\beta$ & $\sigma$ & $\beta$ & $\sigma$ \\
\hline \multirow{3}{*}{$\begin{array}{l}\text { Lerner } \\
\text { index }\end{array}$} & 2008-2012 & $\begin{array}{c}-0.9976^{* * *} \\
(0.1001)\end{array}$ & $\begin{array}{l}0.0031 * \\
(0.0017)\end{array}$ & $\begin{array}{l}-1.0405^{* * *} \\
(0.1450)\end{array}$ & $\begin{array}{l}0.0043 * \\
(0.0022)\end{array}$ & $\begin{array}{c}-0.9490^{* * *} \\
(0.1367)\end{array}$ & $\begin{array}{c}0.0016 \\
(0.0028) \\
\end{array}$ \\
\hline & 2013-2017 & $\begin{array}{c}-0.8851^{* * *} \\
(0.1436)\end{array}$ & $\begin{array}{c}0.0012 \\
(0.0022)\end{array}$ & $\begin{array}{c}-0.9229 * * * \\
(0.2177)\end{array}$ & $\begin{array}{c}0.0026 \\
(0.0026) \\
\end{array}$ & $\begin{array}{c}-0.8542^{* * *} \\
(0.1930)\end{array}$ & $\begin{array}{l}-0.0014 \\
(0.0035) \\
\end{array}$ \\
\hline & 2005-2017 & $\begin{array}{c}-0.4072 * * * \\
(0.0548)\end{array}$ & $\begin{array}{c}0.0018^{* * *} \\
(0.0005)\end{array}$ & $\begin{array}{c}-0.5367^{* * *} \\
(0.0834)\end{array}$ & $\begin{array}{c}0.0023^{* * *} \\
(0.0006)\end{array}$ & $\begin{array}{c}-0.3551^{* * *} \\
(0.0781)\end{array}$ & $\begin{array}{c}0.0011 \\
(0.0008)\end{array}$ \\
\hline \multirow{3}{*}{ HHI } & 2008-2012 & $\begin{array}{c}-0.4009^{* * *} \\
(0.1003)\end{array}$ & $\begin{array}{c}-0.0018^{* *} \\
(0.0008)\end{array}$ & $\begin{array}{c}-0.4112 * * * \\
(0.1203)\end{array}$ & $\begin{array}{c}-0.0022 * \\
(0.0012)\end{array}$ & $\begin{array}{c}-0.3711 * \\
(0.1924)\end{array}$ & $\begin{array}{l}-0.0004 \\
(0.0007)\end{array}$ \\
\hline & 2013-2017 & $\begin{array}{l}-0.1257 \\
(0.1524) \\
\end{array}$ & $\begin{array}{c}-0.0025 * \\
(0.0014)\end{array}$ & $\begin{array}{c}0.1707 \\
(0.1714) \\
\end{array}$ & $\begin{array}{c}-0.0048^{* *} \\
(0.0022)\end{array}$ & $\begin{array}{c}-0.8280 * * * \\
(0.2513)\end{array}$ & $\begin{array}{c}0.0007 \\
(0.0010)\end{array}$ \\
\hline & 2005-2017 & $\begin{array}{c}-0.1210^{* * *} \\
(0.0363)\end{array}$ & $\begin{array}{l}-0.0005 \\
(0.0004)\end{array}$ & $\begin{array}{c}-0.1531^{* * *} \\
(0.0478)\end{array}$ & $\begin{array}{c}-0.0018^{* * *} \\
(0.0005)\end{array}$ & $\begin{array}{l}-0.0914 \\
(0.0558)\end{array}$ & $\begin{array}{c}0.0013 * * * \\
(0.0004)\end{array}$ \\
\hline \multirow{3}{*}{ CR5 } & 2008-2012 & $\begin{array}{c}-0.4466^{* * *} \\
(0.0953)\end{array}$ & $\begin{array}{c}-0.0056^{* * *} \\
(0.0020)\end{array}$ & $\begin{array}{c}-0.4785^{* * *} \\
(0.1099)\end{array}$ & $\begin{array}{c}-0.0070^{* * *} \\
(0.0024)\end{array}$ & $\begin{array}{c}-0.3822 \text { ** } \\
(0.1805)\end{array}$ & $\begin{array}{l}-0.0027 \\
(0.0029)\end{array}$ \\
\hline & 2013-2017 & $\begin{array}{l}-0.1709 \\
(0.1672)\end{array}$ & $\begin{array}{c}0.0030 \\
(0.0022)\end{array}$ & $\begin{array}{c}0.0201 \\
(0.1848)\end{array}$ & $\begin{array}{c}0.0042 \\
(0.0026)\end{array}$ & $\begin{array}{l}-0.4191 \\
(0.3000)\end{array}$ & $\begin{array}{c}0.0035 \\
(0.0033)\end{array}$ \\
\hline & 2005-2017 & $\begin{array}{c}-0.1415^{* * *} \\
(0.0356)\end{array}$ & $\begin{array}{l}-0.0002 \\
(0.0009)\end{array}$ & $\begin{array}{c}-0.2044^{* * *} \\
(0.0486)\end{array}$ & $\begin{array}{l}-0.0008 \\
(0.0008)\end{array}$ & $\begin{array}{c}-0.0941 \text { * } \\
(0.0530)\end{array}$ & $\begin{array}{c}0.0017 \\
(0.0013)\end{array}$ \\
\hline \multirow{3}{*}{ NPL ratio } & 2008-2012 & $\begin{array}{c}-0.7191^{* * *} \\
(0.0829)\end{array}$ & $\begin{array}{c}1.0584^{* * *} \\
(0.1872)\end{array}$ & $\begin{array}{l}-1.0430 \text { *** } \\
(0.0974)\end{array}$ & $\begin{array}{c}0.2944 \\
(0.2230)\end{array}$ & $\begin{array}{c}-0.3218^{* * *} \\
(0.0927)\end{array}$ & $\begin{array}{c}0.9931 \text { *** } \\
(0.1779)\end{array}$ \\
\hline & 2013-2017 & $\begin{array}{c}-0.2679 * * \\
(0.1012)\end{array}$ & $\begin{array}{l}0.2008 * \\
(0.1771)\end{array}$ & $\begin{array}{c}-0.3747^{* * *} \\
(0.1347)\end{array}$ & $\begin{array}{c}-0.2758^{* * *} \\
(0.0910)\end{array}$ & $\begin{array}{l}-0.0174 \\
(0.1426)\end{array}$ & $\begin{array}{c}0.8723 \text { ** } \\
(0.3450)\end{array}$ \\
\hline & 2005-2017 & $\begin{array}{c}-0.2009 * * * \\
(0.0325)\end{array}$ & $\begin{array}{c}0.7479 * * * \\
(0.0793)\end{array}$ & $\begin{array}{c}-0.2817^{* * *} \\
(0.0519)\end{array}$ & $\begin{array}{l}-0.0245 \\
(0.0545)\end{array}$ & $\begin{array}{c}-0.1304^{* * *} \\
(0.0369)\end{array}$ & $\begin{array}{c}1.0566^{* * *} \\
(0.1243)\end{array}$ \\
\hline
\end{tabular}

\footnotetext{
Notes: Standard errors are reported in parentheses. ${ }^{*}, * *$ and ${ }^{* * *}$ indicate statistical significance at the $10 \%, 5 \%$ and $1 \%$ levels respectively. Country dummies are not reported for brevity. Source: BankScope database, ECB, World Bank, own calculations.
}

According to the regression results of Table 7, the Lerner index of market power presented $\beta$-convergence in all country groups across all the three periods examined. These results are generally in accordance with the results of $\beta$-convergence tests, performed by Weill (2013), which suggest that during the period 2002-2010 the least competitive banking systems in the EU-27 experienced a greater improvement in competition than the most competitive banking systems. Regarding $\sigma$-convergence, the related regression coefficient for the period 2008-2012 for both the EA-19 and the EA-Co groups is positive and statistically significant, thus indicating a diverging trend. This coefficient remains positive for the period 2013-2017, however having lost its statistical significance. Regarding the EA-Pe group, its related regression coefficient for the period 2008-2012 was found to be positive, but not statistically significant. In the period 2013-2017, it became negative, but still not statistically significant. According to the regression results for the total period 2005-2017, both the EA-19 and the EA-Co 
groups experienced a diverging trend of market power, while the regression coefficient for the EA-Pe group is positive, but not statistically significant.

The adverse evolution of the $\sigma$-convergence of market power during the period under examination may be attributed to the 2008 crisis, which led to distortions in competition created by the state aid granted to banks, while mergers were allowed without taking into account their effects on market power (Maudos and Vives 2019).

The $\sigma$-convergence related regression coefficient of the HHI concentration measure for both the EA-19 and the EA-Co groups in the period 2008-2012 is negative and statistically significant; thus, indicating a converging trend. The corresponding regression coefficient for the EA-Pe group is also negative, but not statistically significant. Its sign turned to positive in the period 2013-2017, with the coefficient remaining not statistically significant. In addition, the HHI concentration measure did not present $\beta$-convergence in the case of both the EA-19 and the EA-Co groups during this period. Finally, the EA-Co group was the only one that experienced $\sigma$-convergence during the total period 2005-2017. From 2008 to 2012, both the EA-19 and the EA-Co groups experienced $\sigma$-convergence of the CR5 concentration measure, in contrast to the EA-Pe group, the regression coefficient of which was found to be negative, but not statistically significant. The CR5 concentration measure did not present $\beta$-convergence during the period 2013-2017 in any of the three country groups under examination. The regression results also show that none of the three groups experienced $\sigma$-convergence during the total period 2005-2017, with the situation being worse in the case of EA-Pe group.

The observed diverging trends in concentration, measured by the HHI and CR 5 concentration indices, were caused by the global financial crisis of 2008, which accelerated the pace of bank concentration in the countries that had been hit most severely by the crisis and whose banking systems had been subject to restructuring (Maudos and Vives 2019). Concentration in Cyprus and Greece, which were already characterized by highly concentrated banking systems, increased further during the crisis period, widening the gap with Italy, which has the lowest bank concentration in the EA-Pe group, including strong cooperative and savings banking sectors (ECB 2016). Regarding the EA-Co group, which was affected less than the EA-Pe group by the global financial crisis, the observed diverging trends in concentration during the period 2013-2017 may be attributed to the fact that in countries, such as Austria, France, and Luxembourg, which were already characterized by very low bank concentration, concentration decreased further, widening the gap with other more concentrated banking systems in the EA-Co group.

During the period 2008-2012, both the EA-19 and the EA-Pe groups experienced lack of $\sigma$-convergence with respect to the NPL ratio, while the related regression coefficient for the EA-Co group was found to be positive, but not statistically significant. The situation for the EA-Co group changed in the period 2013-2017, since the related regression coefficient not only changed to negative but also became statistically significant; thus, suggesting a clear convergence. In the case of the EA-19 group, the related regression coefficient remained positive. Finally, the NPL ratio did not present $\beta$-convergence in the case of the EA-Pe group during the period 2013-2017. Regarding the total period 2005-2017, both the EA-19 and the EA-Pe groups experienced a clear divergence, in contrast to the EA-Co group, the regression coefficient of which was found to be negative, albeit not statistically significant.

The convergence of the NPL ratio in the EA-Co group during the period 2013-2017 may be attributed to the fact that the countries of this group are characterized by low or relatively low levels of NPLs. Although the NPL levels increased enormously in Latvia and Lithuania at the outburst of the crisis, they entered into a very sharp decreasing path afterwards. On the contrary, the divergence of the NPL ratio in the EA-Pe countries may be attributed to the fact that these countries experienced higher levels of NPLs than the EA-Co countries during the crisis, which remain very high in the case of Cyprus and Greece. 


\section{Conclusions}

In this study, we examined the evolution of competition (through market power and concentration) and credit risk (through non-performing loans) across euro area core (EA-Co), periphery (EA-Pe) and all 19 countries (EA-19) in the period 2005-2017, as well as in two sub-periods, 2008-2012 and 2013-2017. Furthermore, we tested two hypotheses with respect to competition, concentration and credit risk: (a) the existence of fragmentation in the euro area as a whole (EA-19), as well as in core countries (EA-Co) and periphery countries (EA-Pe), and (b) the presence of $\beta$-convergence and $\sigma$-convergence among the country-members of each of the three groups.

Our analysis extends beyond the period of financial crisis, thereby taking into account the non-standard measures adopted by the ECB to support further integration. By using data from all the 19 euro area countries, which have a common currency and a single bank supervisory mechanism, a possible bias that might stem from the use of either heterogeneous data or data coming from only a subset of euro area countries was eliminated, allowing for robust testing of fragmentation and converging or diverging trends. In addition to uncovering the evolution of bank competition and risk, providing substantiated clues to policy makers about the progress of integration was a major aim of our research.

Competition (as expressed by the inverse of the Lerner index of market power) reached a minimum in 2015 and increased afterwards in all three country groups under examination (EA-19, EA-Co and EA-Pe), in line with a gradual but fragile post-crisis reintegration trend. This is supported by the Theil inequality index for market power, which reveals a decrease of the between-country inequality from 2011 onwards in each of the three groups. This evolution was also confirmed by means of $\beta$-convergence and $\sigma$-convergence tests, which showed a decrease in divergence of competition. Another finding is that the global financial crisis reversed the advances in competitive pressure that had been observed during the preceding few years.

With respect to concentration, as measured by the HHI and CR 5 concentration indices, the average concentration in EA-19 and EA-Co started decreasing in 2015 and 2012, respectively, in contrast to EA-Pe, where concentration has followed a continuously increasing path since 2007. The progress that had been made during the period 2008-2012 with the achievement of $\beta$-convergence and $\sigma$-convergence in the whole euro area and the core countries was reversed in the period 2013-2017. Periphery countries did not experience convergence of concentration in either of the two periods 2008-2012 and 2013-2017.

Regarding credit risk, NPL ratios have always been higher in EA-Pe. Moreover, while the weighted average of the NPL ratio in EA-Co peaked in 2013 at 3.38\%, in EA-Pe the peak of 15.56\% was in 2014. The decrease thereafter has not been proportional between the two groups, in line with the $\beta$-convergence and $\sigma$-convergence tests, which indicate that the EA-Co group experienced $\beta$-convergence and $\sigma$-convergence in the period 2013-2017, while the EA-Pe group has been characterized by divergence. The Theil inequality index confirms the divergence between the two groups, indicating that the inequality between the EA-Co and the EA-Pe groups has been continuously increasing since 2008. This evolution suggests that the presence of persistent large stocks of NPLs remains a pressing challenge, which contributes to fragmentation between euro area countries. Hence, more effective measures, such as the creation of asset management companies, NPL transaction platforms, securitization, or state guarantees schemes, should be introduced in order not only to reduce the existing NPL volumes, but also to prevent their increase in the future.

All in all, the persistence of fragmentation, in spite of some partial reintegration trends, suggests that policy measures accelerating convergence of our variables would not only strengthen financial integration, but also help in establishing a real euro area banking union.

Author Contributions: Conceptualization, M.K. and H.L.; methodology, M.K. and H.L.; software, M.K.; validation, M.K.; formal analysis, M.K.; investigation, M.K.; resources, M.K.; data curation, M.K.; writing-original draft preparation, M.K.; writing-review and editing, M.K. and H.L.; visualization, M.K. and H.L.; supervision, H.L.; project administration, H.L.; funding acquisition, H.L. All authors have read and agreed to the published version of the manuscript. 
Funding: Financial assistance from the Research Centre of the Athens University of Economics and Business.

Acknowledgments: The authors would like to thank participants at the ASSET Conference (Athens 2019), FEBS Conferences (Athens 2019; Prague 2019), JIMF Conference (Marrakech 2019), and EBES Conference (Kuala Lumpur 2020), for discussing and commenting on many of the research questions and approaches of this paper.

Conflicts of Interest: The authors declare no conflict of interest.

\section{References}

Al-Eyd, Ali, and Pelin Berkmen. 2013. Fragmentation and Monetary Policy in the Euro Area. Working Paper No. 13/208, International Monetary Fund, Washington, DC, USA.

Anastasiou, Dimitrios, Helen Louri, and Mike Tsionas. 2019. Non-Performing Loans in the Euro-area: Are Core-Periphery Banking Markets Fragmented? International Journal of Finance and Economics 24: 97-112. [CrossRef]

Angelini, Paolo, and Nicola Cetorelli. 2003. The Effects of Regulatory Reform on Competition in the Banking Industry. Journal of Money, Credit and Banking 35: 663-84. [CrossRef]

Apergis, Nicholas, Irene Fafaliou, and Michael L. Polemis. 2016. New evidence on assessing the level of competition in the European Union banking sector: A panel data approach. International Business Review 25: 395-407. [CrossRef]

Baele, Lieven, Annalisa Ferrando, Peter Hördahl, Elizaveta Krylova, and Cyril Monnet. 2004. Measuring Financial Integration in the Euro Area. Occasional Paper No. 14. Frankfurt: European Central Bank.

Barro, Robert J., and Xavier Sala-i-Martin. 1991. Convergence across states and regions. Brookings Papers on Economic Activity 1: 107-82. [CrossRef]

Berenberg-Gossler, Paul, and Henrik Enderlein. 2016. Financial Market Fragmentation in the Euro Area: State of Play. Policy Paper No. 177. Berlin: Jacques Delors Institut.

Bikker, Jacob A., and Katharina Haaf. 2002. Competition, concentration and their relationship: An empirical analysis of the banking industry. Journal of Banking and Finance 26: 2191-214. [CrossRef]

Bikker, Jacob A., and Laura Spierdijk. 2008. How Banking Competition Changed over Time. Working Paper No. 167, De Netherlandsche Bank, Amsterdam, The Netherlands.

Boone, Jan. 2008. A new way to measure competition. Economic Journal 118: 1245-61. [CrossRef]

Casu, Barbara, and Claudia Girardone. 2009. Competition issues in European banking. Journal of Financial Regulation and Compliance 17: 119-33. [CrossRef]

Claessens, Stijn. 2019. Fragmentation in Global Financial Markets: Good or Bad for Financial Stability? BIS Working Papers No. 815, Bank for International Settlements, Basel, Switzerland.

Coccorese, Paolo. 2004. Banking competition and macroeconomic conditions: A disaggregate Analysis. Journal of International Financial Markets, Institutions and Money 14: 203-19. [CrossRef]

Cruz-Garcia, Paula, Juan Fernandez de Guevara, and Joaquin Maudos. 2017. The evolution of market power in European banking. Finance Research Letters 23: 257-62. [CrossRef]

De Bandt, Olivier, and E. Philip Davis. 2000. Competition, contestability and market structure in European banking sectors on the eve of EMU. Journal of Banking and Finance 24: 1045-66. [CrossRef]

De Sola Perea, Maite, and Christophe Van Nieuwenhuyze. 2014. Financial integration and fragmentation in the euro area. Economic Review, 99-125, June. Brussels: National Bank of Belgium.

ECB. 2003. The Integration of Europe's Financial Markets. European Central Bank Monthly Bulletin. Frankfurt: European Central Bank.

ECB. 2016. Report on Financial Structures. Frankfurt: European Central Bank.

ECB. 2018. Financial integration in Europe. Frankfurt: European Central Bank.

ECB. 2019a. Statistical Data Warehouse: Balance Sheet Items Statistics. Available online: https://sdw.ecb.europa. eu/browse.do?node=1491 (accessed on 3 September 2019).

ECB. 2019b. Statistical Data Warehouse: Banking Structural Financial Indicators Statistics. Available online: https://sdw.ecb.europa.eu/browseSelection.do?node=9689719 (accessed on 3 September 2019).

ECB. 2020. Supervisory Banking Statistics-Third Quarter 2019. Frankfurt: European Central Bank.

Fernandez de Guevara, Juan, Joaquin Maudos, and Francisco Perez. 2007. Integration and competition in the European financial markets. Journal of International Money and Finance 26: 26-45. [CrossRef]

FSB. 2019. FSB Report on Market Fragmentation. Basel: Financial Stability Board. 
Gischer, Horst, and Mike Stiele. 2008. Competition Tests with a Non-Structural Model: The Panzar-Rosse Method Applied to Germany's Savings Banks. German Economic Review 10: 50-70. [CrossRef]

Goddard, John, Hong Liu, Phil Molyneux, and John O. S. Wilson. 2013. Do Bank Profits Converge? European Financial Management 19: 345-65. [CrossRef]

Hondroyiannis, George, Sarantis Lolos, and Evangelia Papapetrou. 1999. Assessing competitive conditions in the Greek banking system. Journal of International Financial Markets, Institutions and Money 9: 377-91. [CrossRef]

Jondrow, James, C. A. Knox Lovell, Ivan S. Materov, and Peter Schmidt. 1982. On the estimation of technical inefficiency in the stochastic frontier production function model. Journal of Econometrics 19: 233-38. [CrossRef]

Karadima, Maria, and Helen Louri. 2019. Non-Performing Loans in the Euro Area: Does Market Power Matter? Working Paper No. 271, Bank of Greece, Athens, Greece.

Kumbhakar, Subal C., Sjur Baardsen, and Gudbrand Lien. 2012. A new method for estimating market power with an application to Norwegian sawmilling. Review of Industrial Organization 40: 109-29. [CrossRef]

Lapteacru, Ion. 2018. Convergence of bank competition in Central and Eastern European countries: do foreign and domestic banks go hand in hand? Post-Communist Economies 30: 588-616. [CrossRef]

Lerner, Abba P. 1934. The concept of monopoly and the measurement of monopoly power. Review of Economic Studies 1: 157-75. [CrossRef]

Louri, Helen, and Petros Migiakis. 2019. Bank lending margins in the euro area: Funding conditions, fragmentation and ECB's policies. Review of Financial Economics 37: 482-505. [CrossRef]

Lucotte, Yannick. 2015. Euro area banking fragmentation in the aftermath of the crisis: A cluster analysis. Applied Economics Letters 22: 1046-50. [CrossRef]

Magnus, Marcel, Alienor Margerit, Benoit Mesnard, and Christina Katopodi. 2017. Non-Performing Loans in the Banking Union-Stocktaking and Challenges. European Parliament Briefing, 13 July. Brussels: European Parliament.

Maudos, Joaquin, and Xavier Vives. 2019. Competition Policy in Banking in the European Union. Review of Industrial Organization 55: 27-54. [CrossRef]

Moch, Nils. 2013. Competition in fragmented markets: New evidence from the German banking industry in the light of the subprime crisis. Journal of Banking and Finance 37: 2908-19. [CrossRef]

Panzar, John C., and James N. Rosse. 1987. Testing for "monopoly" equilibrium. Journal of Industrial Economics 35: 443-56. [CrossRef]

Phillips, Peter, and Donggyu Sul. 2007. Transition modeling and econometric convergence tests. Econometrica 75: 1771-855. [CrossRef]

Staikouras, Christos K., and Anastasia Koutsomanoli-Filippaki. 2006. Competition and Concentration in the New European Banking Landscape. European Financial Management 12: 443-82. [CrossRef]

Sun, Yu. 2009. Recent Developments in European Bank Competition. Working Paper No. 11/146, International Monetary Fund, Washington, DC, USA.

Weill, Laurent. 2013. Bank competition in the EU: How has it evolved? Journal of International Financial Markets, Institutions and Money 26: 100-12. [CrossRef]

World Bank. 2019a. World Development Indicators Database. Available online: https://databank.worldbank.org/ source/world-development-indicators (accessed on 28 October 2019).

World Bank. 2019b. Global Financial Development Database. Available online: https://datacatalog.orldbank.org/ dataset/global-financial-development (accessed on 28 October 2019).

(C) 2020 by the authors. Licensee MDPI, Basel, Switzerland. This article is an open access article distributed under the terms and conditions of the Creative Commons Attribution (CC BY) license (http://creativecommons.org/licenses/by/4.0/). 